\title{
WestVirginiaUniversity
}

THE RESEARCH REPOSITORY @ WVU

Graduate Theses, Dissertations, and Problem Reports

2013

\section{Factors considered for increasing longwall panel width}

Jack D. Trackemas

West Virginia University

Follow this and additional works at: https://researchrepository.wvu.edu/etd

\section{Recommended Citation}

Trackemas, Jack D., "Factors considered for increasing longwall panel width" (2013). Graduate Theses, Dissertations, and Problem Reports. 175.

https://researchrepository.wvu.edu/etd/175

This Thesis is protected by copyright and/or related rights. It has been brought to you by the The Research Repository @ WVU with permission from the rights-holder(s). You are free to use this Thesis in any way that is permitted by the copyright and related rights legislation that applies to your use. For other uses you must obtain permission from the rights-holder(s) directly, unless additional rights are indicated by a Creative Commons license in the record and/ or on the work itself. This Thesis has been accepted for inclusion in WVU Graduate Theses, Dissertations, and Problem Reports collection by an authorized administrator of The Research Repository @ WVU. For more information, please contact researchrepository@mail.wvu.edu. 


\title{
FACTORS CONSIDERED FOR INCREASING LONGWALL PANEL WIDTH
}

\author{
by
}

Jack D. Trackemas

Thesis submitted to the College of Engineering and Mineral Resources at West Virginia University in partial fulfillment of the requirements for the degree of

\author{
Master of Science \\ in \\ Mining Engineering
}

\begin{abstract}
Approved by Brijes Mishra, Ph.D.

Yi Luo, Ph.D.

Mining Engineering

Morgantown, West Virginia

May 2013
\end{abstract}

Syd S. Peng Ph.D., Committee Chairperson

Keywords: Longwall Mining; Panel Width; Coal Extraction Copyright 2013 Trackemas 


\section{Abstract \\ FACTORS CONSIDERED FOR INCREASING LONGWALL PANEL WIDTH}

\section{by Jack $\mathrm{D}$. Trackemas}

Longwall mining is the preferred method in coal mining to maximize production and reserve recovery by extracting large blocks of coal that have been outlined with a set of continuous miner development entries. In the US, technological advances and system enhancements have steadily improved productivity more in the longwall retreat process as compared to the improvements in continuous miner gateroad development process. Consequently, longwall extraction rates have outpaced gateroad development mining advancement.

This thesis addresses the factors considered for increasing panel width and the solutions to the technical concerns for increasing the longwall face width from the current accepted industry standard of 1050 feet to 1600 feet $(320 \mathrm{~m}$ to $488 \mathrm{~m})$. The process of increasing the width of longwall panels, while helping to increase coal production, reducing continuous miner development, and increasing coal reserve recovery, will result in additional design considerations for equipment, roof control, ventilation design, infrastructure, and longwall moves. This thesis will discuss the areas for design considerations and solutions to the technical concerns. 


\section{DEDICATION}

The author wishes to dedicate this thesis to my parents, my wife Terri, and my children for their support, companionship, and understanding though the years. 


\section{ACKNOWLEDGMENTS}

I express my sincere appreciation to Dr. Syd Peng, my graduate advisor and committee Chair for his help and encouragement. His passion for improving mining technology has encouraged many of us to push forward toward new ideas and accomplishments.

I am thankful to my industry colleagues, especially Dr. Klaus Beck, Mike Mishra, and others too numerous to mention, for their help, assistance, and support through the years. 


\section{TABLE OF CONTENTS}

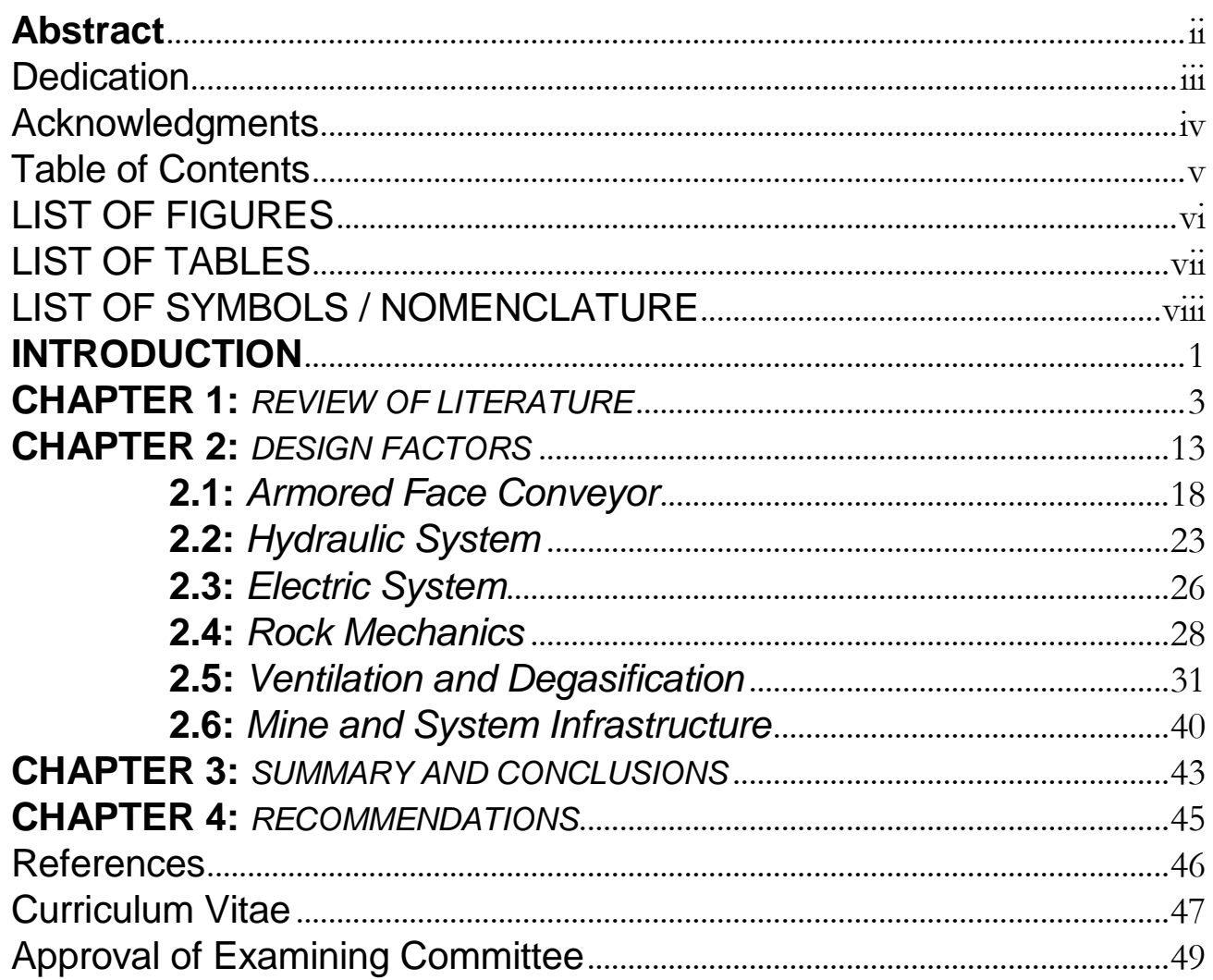




\section{LIST OF FIGURES}

Figure 1: Trend of Continuous Miner Production Rates Compared to Longwall Production Improvements for a typical Pittsburgh No.8 Coal Mine ..............................

Figure 1-1: Self-Advancing Hydraulic Roof Supports ("Frames") ..........5

Figure 1-2: Longwall Face at Sunnyside Mine Using Self-advancing Hydraulic Roof Supports ("Frames")....................................

Figure 1-3: "Anderton" Shearer/Loader ..............................................

Figure 1-4: "Dowty" Chock Roof Support ..............................................8

Figure 2-1: Face Equipment Testing During Compatibility in Manufacturer's Shop......................................................17

Figure 2-2: Measurement Data from Loading of Armored Face Conveyor.................................................................22

Figure 2-3: Flow Demand for Pressures Calculations.........................23

Figure 2-4: Hydraulic Schematic of 1,050 feet wide longwall base case. 24

Figure 2-5: Typical Longwall Face Ventilation Currently Used During Study .32

Figure 2-6: Instrument Locations for Methane Emissions ....................33

Figure 2-7: Methane Emissions Recordings .....................................35

Figure 2-8: Methane Emissions Interval Recordings .........................36

Figure 2-9: Regression Analysis Results 40 


\section{LIST OF TABLES}

Table 1.1: Distribution of Longwall Units, by Face Width, 1984, 1988 , and 1993

Table 1.2: Productivity Improvements .............................................10

Table 1.3: Panel Design for a District Comparison ..............................11

Table 1.4: Panel Design for Shield Cycle Comparison ........................12

Table 2.1: Armored Face Conveyor design calculations.......................20

Table 2.2: Details of the hydraulic system hosing .............................25

Table 2.3: Pressures Loss Calculations for increased face length ......26

Table 2.4: Change in face advancement..........................................29

Table 2.5: Comparison of weight for drive units .................................30

Table 2-6: Face ventilation resistance and quantity requirements.......37

Table 2.7: Increase in raw tons for extended panel widths ..................42 


\section{LIST OF SYMBOLS / NOMENCLATURE}

1. $\mathrm{CM}$ - continuous miner

2. LW - longwall

3. AFC - armored face conveyor

4. RPM - revolutions per minute

5. cfm - cubic feet per minute

6. psi-pounds per square inch

7. PLC - programmable logic controller

8. CST - control start transmission 


\section{INTRODUCTION}

Over the past several decades, coal companies have installed new designed longwall equipment and increased longwall face productivity at coal mining operations. With the new designed equipment, most major coal companies have strategically increase the width and length of longwall panels to reduce the amount of continuous miner development required to keep pace with the increased longwall retreat productivities. Face widths of 500 feet to 600 feet $(150 \mathrm{~m}$ to 180 $\mathrm{m})$ in the 1970's and early 1980's, were increased to 800 feet $(245 \mathrm{~m})$ wide panels by the mid to late 1980's, and then 1000 feet (305 m) in the mid to late 1990's. Current technology of the early years of the 2000's has supported 1050 feet (320 $\mathrm{m}$ ) wide faces. The limiting technology, especially concerning the face conveyor, consisted of fluid couplings type conveyor drives, Depicted in the Figure 1 is an example of a typical Pittsburgh No. 8 longwall mine showing the effects of increased longwall face width and new equipment technology on production. The figure shows the trend of production change from a nominal 600 feet $(180 \mathrm{~m})$ width face to 800 feet $(243 \mathrm{~m})$ width face in 1991 . The production prior to 1991 averaged approximately 2,500 raw tons $(2,270 \mathrm{t})$ per shift. The increase in face width yielded an impressive gain to over 4,000 raw tons (3,640 t) per shift. The figure also indicates the production gain from the purchase of new longwall equipment with design improvements in 1994 . The new equipment allowed the mine to improve production to over 6,000 raw tons $(5,455 \mathrm{t})$ per shift. The new equipment included better hydraulic electric controls, higher support densities, and most importantly effective shield base lift capabilities for dealing with soft floor conditions. The effects of increases in face width are depicted in 1998 from 800 feet $(243 \mathrm{~m})$ width to 900 feet $(274 \mathrm{~m})$ width, and then again from 900 feet $(274 \mathrm{~m})$ width to 1050 feet $(320 \mathrm{~m})$ width in 2001 . With the increase in face width to 900 feet $(275 \mathrm{~m})$, the mine produced over 9000 raw tons $(8,182 \mathrm{t})$ per shift. The additional increase to 1050 feet $(320 \mathrm{~m})$ allowed the mine to reach a new milestone with an average of 10,000 raw tons $(9,091 \mathrm{t})$ per shift. The figure also 
indicates that little improvement in CM development productivity has occurred through the entire timeframe, despite all the new types of machines and varying technology used. The figure also indicates a few drops in longwall productivity between the years of 1996 and 1998, which was a result of a combination of longwall float time issues with the CM development not being ready, and longwall bleeder roof control issues and ventilation issues.

\section{CM vs LW Production Trends}
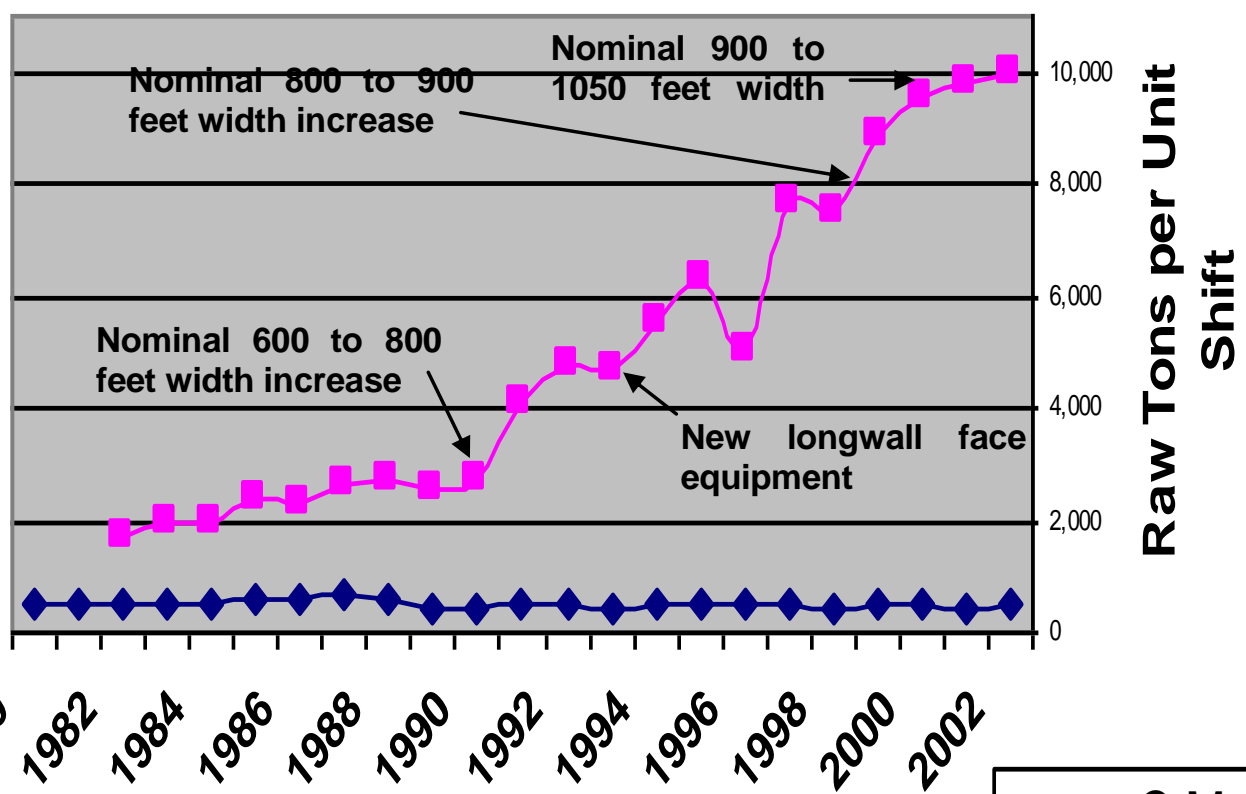

Calendar Year

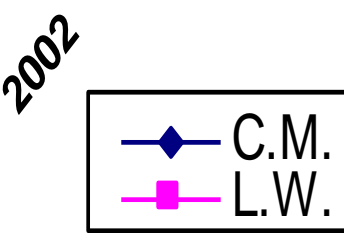

Figure 1: Trend of Continuous Miner Production Rates Compared to Longwall Production Improvements for a typical Pittsburgh No. 8 Coal Mine ${ }^{1}$.

\footnotetext{
${ }^{1}$ Data in Figure was obtained by author for a presentation at the 2003 Voest Alpine Mining Symposium in Austria.
} 


\section{CHAPTER 1: REVIEW OFLITERATURE}

Coal mining began in Pennsylvania in the mid -1700's. The initial reason was to support the Colonial Iron Industry and then Andrew Carnegie's steel mills in the 1800's. Bituminous coal was first mined in Pennsylvania at "Coal Hill" (Mount Washington), just across the Monongahela River from the city of Pittsburgh. The coal was extracted from drift mines in the Pittsburgh coal seam, which outcrops along the hillside, and transported by canoe to the nearby military garrison. By 1830 , the city of Pittsburgh consumed more than 400 tons per day of bituminous coal for domestic and light industrial use. Bituminous coal production increased principally with western population growth, expansion and development of rail and river transportation facilities to the west, and the emergence of the steel industry. The demand for steel generated by the industrial revolution in the last half of the nineteenth century caused an explosive growth of coal.

As World War I escalated around the globe, a coal boom followed, the demand for coal grew to unprecedented heights. Mining companies began recruiting large numbers of immigrants to join the workforce. After World War I ended and European mines reopened, the demand for American coal fell sharply. Over expansion of the coal industry in the United States during the early part of the century, led to its collapse. Prices dropped sharply, and coal companies cut wages to be competitive. Many mines closed completely, thousands of mines went bankrupt or were consolidated into larger mines. Beginning in the 1920s, the coal industry began to compete with oil and natural gas. Coal was being squeezed between cheap oil and natural gas market expansion on the one hand and declining needs by traditional customers resulting in decreases in coal consumption by both railroads and public utilities. Between 1929 and World War II, no industry was hit as hard as the coal. The only way to cut costs and stay in business was mechanization, which was already in full swing by 1929 . To what extent these ideas were adopted or practiced is difficult to quantify, but "hand 
loading" continued to be a drain on the industry, and as more mines shut or slowed production, it was always the mechanized mines that were able to hold on. As the United States was dealing with the Depression, economic recovery was still slow and somewhat fragile. Though coal show some signs of improvement and production was increasing and new mines opening, labor's much increased power and government regulation had altered the mining dynamics.

Mechanization was still the key to success for U.S. mines to be healthier than they were before. Although the U.S. was the largest coal producer worldwide and the global leader in using mobile loaders underground, Great Britain was still far ahead in mechanization, producing more than 54\% of their total output in 1939 by machine.

World War II brought a temporary boom back to the coal industry, the coal companies began using more efficient mining machines instead of hiring additional manpower. The coal industry channeled their efforts toward getting more out of what was on hand or could be acquired; thus resulting in an active installation of new mechanized mining equipment that was supplemented by the adoption of modern auxiliary equipment and up-to-date working methods. Bituminous coal production had hit highs not seen since 1918.

After World War II, U.S. interest in longwall mining was renewed by the possibilities of using the German longwall technology. This technology consisted of the German developed plow and armored face conveyor. The U.S. Bureau of Mines, tested longwall mining with a plow and armored face conveyor at the Statesbury mine, near Beckley, West Virginia. The test was successful and was used to do similar test in three other operations between 1952 and 1958. During the period from 1950 to1960, there was an average of six longwalls in operation per year in the US. Most of these operations were located in West Virginia and Pennsylvania. These longwall systems had limited success due to the coal seams not being friable enough to be plowed and also by roof control problems. Due to the labor intensive roof support system, high capital 
expenditure, and limited success, longwall mining became viewed as a last resort.

In the 1960's, interest in longwall mining in the United States revived, and the number of installations rose to about 20 before 1970 . The main reason for this revival was the introduction of self-advancing hydraulic roof supports ("frames") eliminating the labor intensive supports previously used. This new support system was first used in 1960 at Eastern Associates' Keystone mine near Welch, West Virginia to excavate a 52 -inch (1.32 m) coal seam. In December 1961, Coal Age reviewed the operating results of newly installed longwall technology at the Keystone mine owned by Eastern Gas \& Fuel Associates in West Virginia. Manufactured by Westfalia Lunen, Germany, and marketed by Mining Progress Inc. These supports allowed a 50\% reduction in manpower, improved roof control, increased production, and minimal maintenance and supply costs. West German and British equipment was field tested in the U.S. in 1961 and 1962 and several longwall units were installed during the decade. The supports were also able to push the conveyor forward as the face advanced.

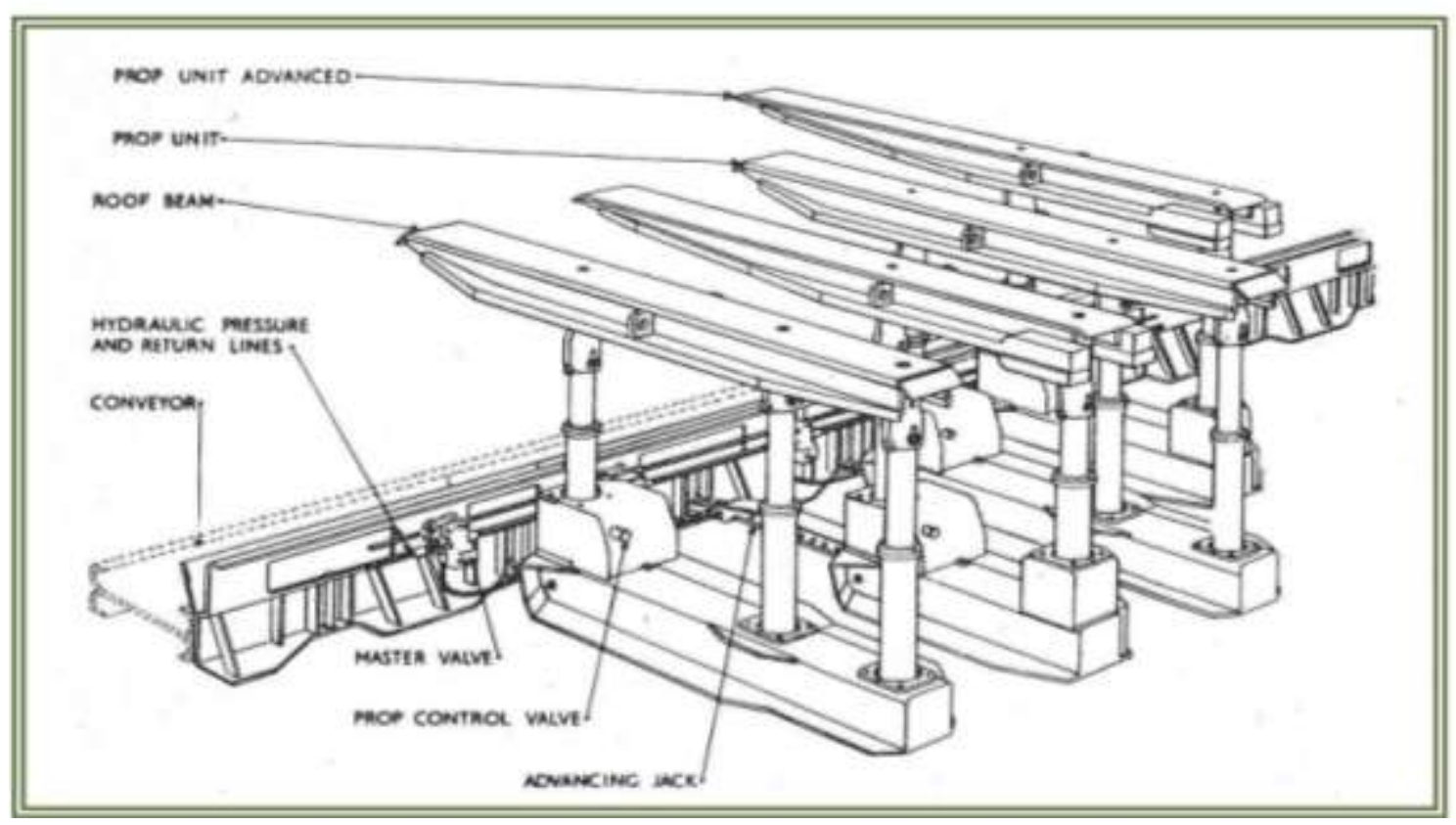

Figure 1-1: Self-Advancing Hydraulic Roof Supports ("Frames") ${ }^{1}$

${ }^{1}$ Photo was taken from Coal Age Magazine December 1961, reprint August 2012. 


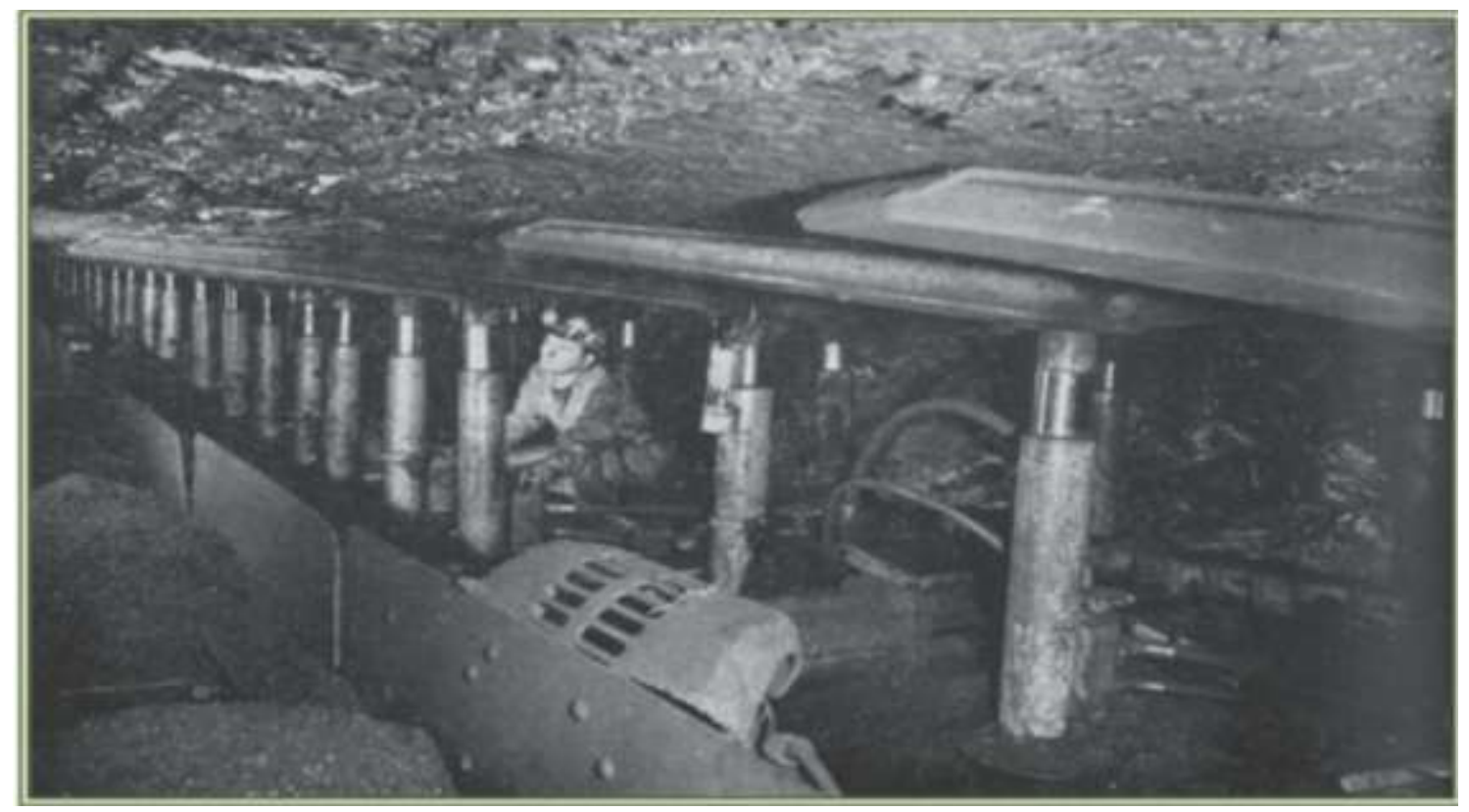

Figure 1-2: Longwall Face at Sunnyside Mine Using Self-advancing Hydraulic Roof Supports ("Frames")

In the early and mid 1960's, longwall mining equipment technology continued to improve. The first shearing machine in the United States was introduced at Kaiser Steel Corporation's Sunnyside No. 3 Mine in Utah in 1961, and later in mines in the East. The Kaiser Steel began operating an experimental face with a width of 308 feet. The face was equipped with an Anderton shearerloader with a 5 foot drum diameter and 27 inches wide; a British Jeffery-Diamond face conveyor; and a Dowty Roofmaster support system. The horsepower of the shearer was 125 horsepower and weighed about 8 tons including the plow. The machine works by "shearing" coal from a longwall coal face as it moved along the face. The machine travels on an armored conveyor and requires a prop-free front for working. It shears the coal in one direction and the front coal is loaded by a plow deflector, and then returns along the face (without cutting) and loads the remainder of the broken coal. The ordinary Anderton is suitable for coal seams more than $3 \mathrm{ft} 6$ in $(1.1 \mathrm{~m})$ thick.

2 Photo was taken from Coal Age Magazine December 1961, reprint August 2012. 


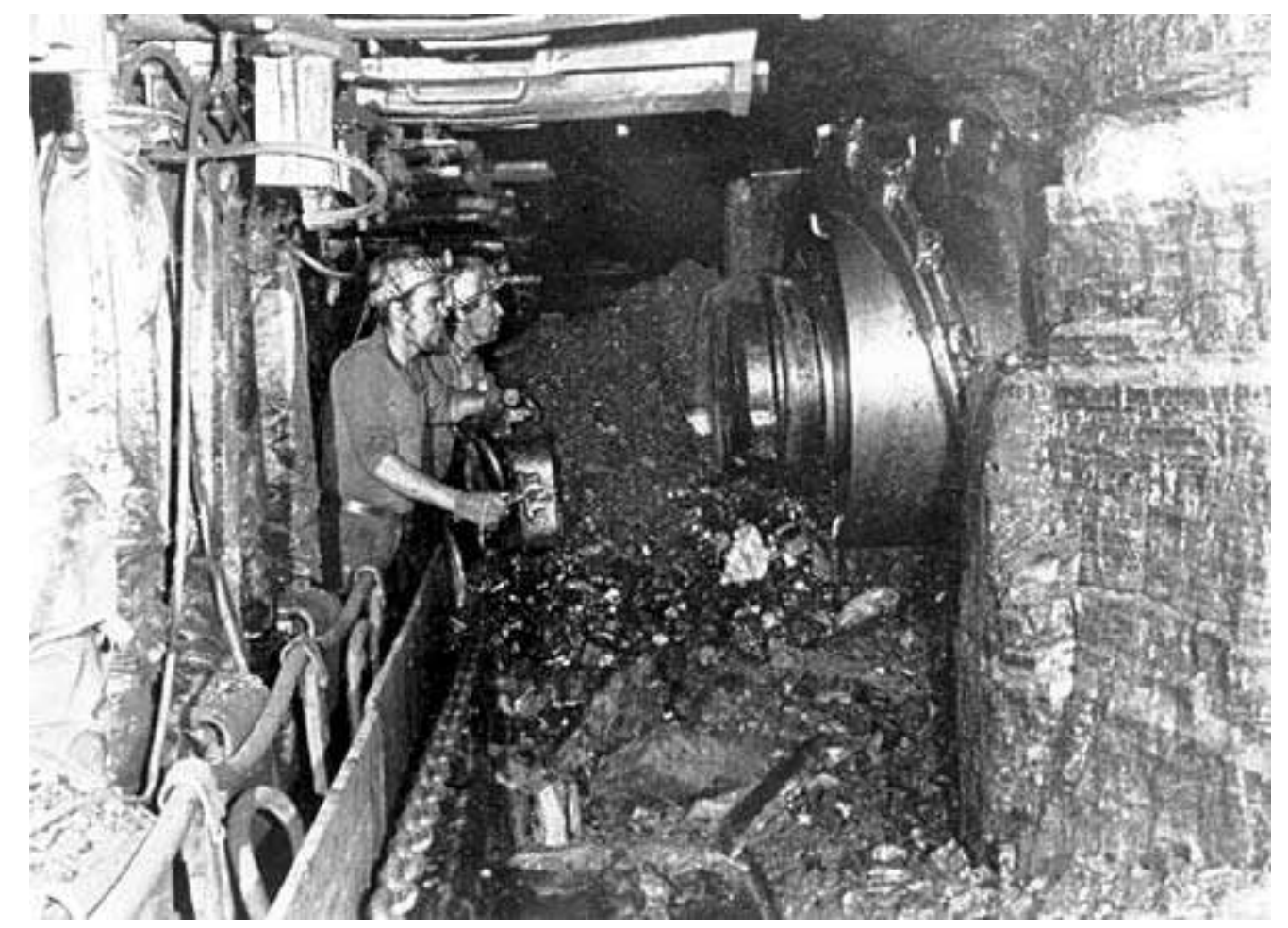

Figure 1-3: "Anderton" Shearer/Loader ${ }^{3}$

During the mid 1960's new improved roof supports ("chocks"), were introduced with supports designs capable of holding about 700 tons. This new longwall equipment continued to have limitations relative to limited horsepower and roof support stability when caving of large blocks occurred; however, longwall installations in the United States continued to grow.

In the 1970's, the last major acceptance of longwall mining in the United States was overcome through the introduction of new roof supports ("shields"). The first shields were installed in 1975 at the Shoemaker mine of Consolidation Coal Company, near Moundsville, West Virginia. Proving successful, "shield" roof support design were applied to other U.S. longwall operations in areas where other roof supports had failed. Improvements were also made to the double-drum and ranging arm shearers developed in the 1960's; therefore, making their cutting height adjust quickly when coal seam thickness changed, or

\footnotetext{
${ }^{3}$ Photo was taken from internet Coal, Colliery, and Mining Forum - healeyhero.co.uk
} 


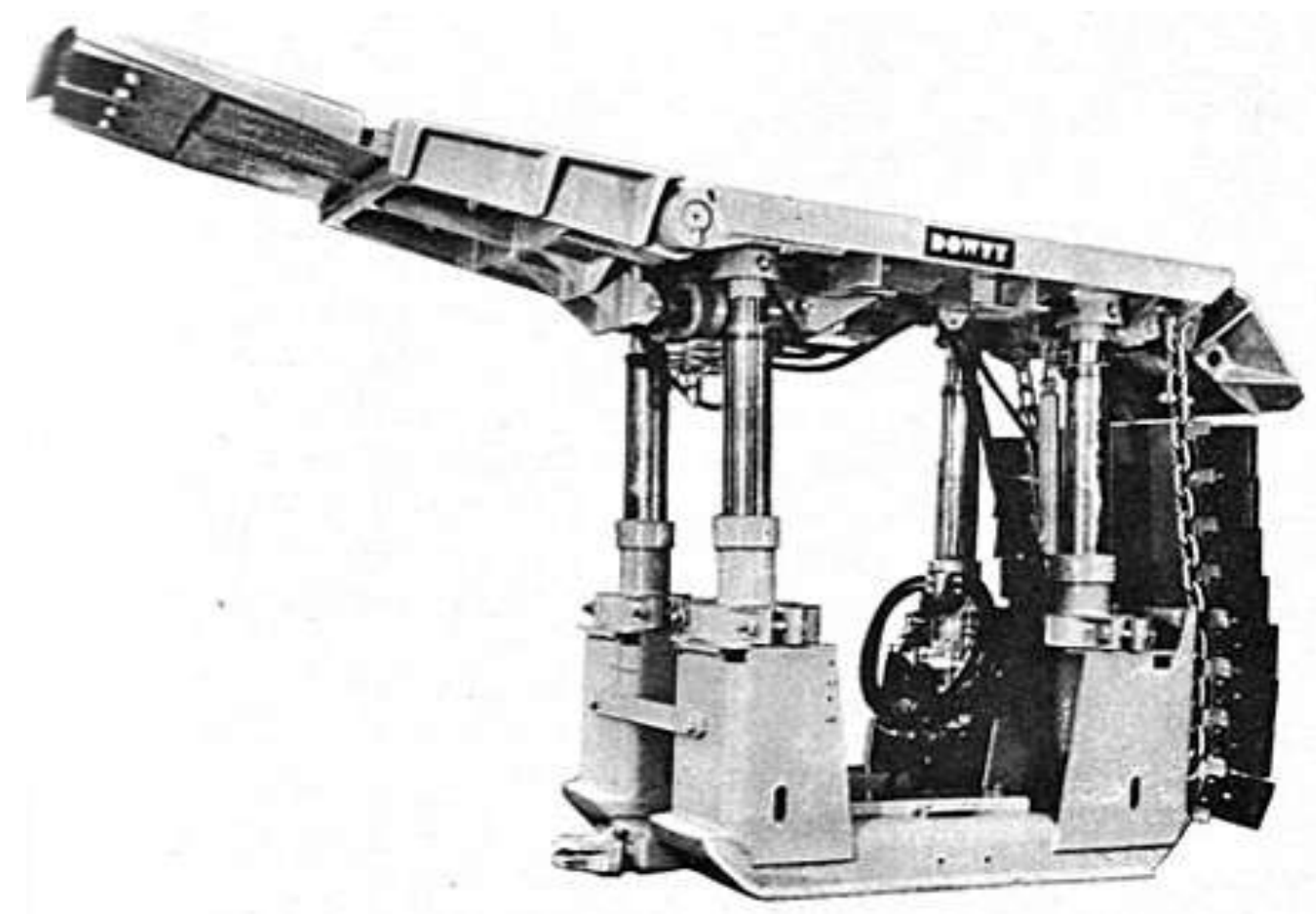

Figure 1-4: "Dowty" Chock Roof Support ${ }^{4}$

when it was necessary to leave a layer of coal at the top of the bed to strengthen the mine roof. More importantly, with regards to face width, improvements were made in the method of hauling the shearer across the coal face. Early shearers were pulled by chains stretched along the length of the face. By the early 1970's, shearers moved by "chainless" methods using self-contained traction units. This early technology generally prohibited longwall face widths greater than 500 feet.

As technology improved by 1984,81 percent of the longwall face widths in the United States fell within the 401 feet $(122 \mathrm{~m})$ to 600 feet $(183 \mathrm{~m})$ width range. See Table 1-1. By 1988, 77 percent of the longwall faces operating in the United States had face widths that operated within the width range of 501 feet $(153 \mathrm{~m})$ to 800 feet $(244 \mathrm{~m})$. By 1993 , over $80 \%$ of the longwall faces had a face width greater than 601 feet $(183 \mathrm{~m}$ ), with two longwall faces exceeding 1,000 feet (305 $\mathrm{m})$ in width.

\footnotetext{
${ }^{4}$ Photo was taken from internet Longwall Mining - www.techcorr.com
} 
Table 1-1: Distribution of Longwall Units, by Face Width, 1984, 1988, and 1993

Notes: In the few cases where a range, rather than a single value, was provided for the face width of a longwall unit, the median was taken as the face width. Also, the face width was not reported for one longwall unit in 1984. Percentages may not add to 100 because of independent rounding ${ }^{5}$.

\begin{tabular}{|c|c|c|c|c|c|c|}
\hline \multirow[b]{2}{*}{$\begin{array}{c}\text { Face Width Range } \\
\text { (feet) }\end{array}$} & \multicolumn{2}{|c|}{1984} & \multicolumn{2}{|c|}{1988} & \multicolumn{2}{|c|}{1993} \\
\hline & $\begin{array}{l}\text { Number } \\
\text { of Units }\end{array}$ & $\begin{array}{l}\text { Percent } \\
\text { of Total }\end{array}$ & $\begin{array}{l}\text { Number } \\
\text { of Units }\end{array}$ & $\begin{array}{l}\text { Percent } \\
\text { of Total }\end{array}$ & $\begin{array}{l}\text { Number } \\
\text { of Units }\end{array}$ & $\begin{array}{l}\text { Percent } \\
\text { of Total }\end{array}$ \\
\hline$<400, \ldots \ldots \ldots \ldots \ldots$ & 8 & 7.2 & 2 & 2.2 & 0 & 0.0 \\
\hline $401-500 \ldots \ldots \ldots \ldots$ & 36 & 32.4 & 9 & 9.8 & 2 & 2.4 \\
\hline $501-600 \ldots \ldots \ldots \ldots \ldots$ & 54 & 48.6 & 30 & 32.6 & 13 & 15.3 \\
\hline $601-700 \ldots \ldots \ldots \ldots$ & 10 & 9.0 & 20 & 21.7 & 10 & 11.8 \\
\hline $701-800, \ldots \ldots \ldots \ldots \ldots$ & 1 & 0.9 & 21 & 228 & 32 & 37.6 \\
\hline $801-900 \ldots \ldots \ldots \ldots$ & 1 & 0.9 & 8 & 8.7 & 18 & 21.2 \\
\hline $901-1,000 \ldots \ldots \ldots \ldots \ldots$ & 1 & 0.9 & 2 & 2.2 & 8 & 9.4 \\
\hline$>1,000 \ldots \ldots \ldots \ldots \ldots$ & 0 & 0.0 & 0 & 0.0 & 2 & 2.4 \\
\hline Total $\ldots \ldots \ldots \ldots \ldots . . . . . .$. & 111 & 100.0 & 92 & 100.0 & 85 & 100.0 \\
\hline
\end{tabular}

Technology has improved allowing for the consideration of wider faces and therefore achieving greater benefits. The benefits of wide-face longwalls can be summarized below:

1. Improved longwall productivity since less time is spent in the wedge cuts at each gate end of the faces; consequently, a higher percentage of the time is spent mining coal from the middle of the face.

2. Reduction of higher cost CM development and the ability to maintain float time.

3. Improved reserve recovery due to the increase in longwall mining panel width and reduction in $\mathrm{CM}$ development mining in reserve blocks.

4. Reduced construction work associated with mining.

5. Delayed timing of capital for subsequent face replacement.

The productivity of the longwall with wider faces improves because a higher percentage of the time is spent mining, and a reduced amount of time is spent in the wedge cuts at each gate end of the face. Table 1.2 illustrates the expected productivity increase of the longwall for the different face widths.

\footnotetext{
5 Table was obtained from publication "Longwall Mining", Energy Information Administration, Office of Coal, Nuclear, Electric and Alternate Fuels, U.S. Department of Energy, March 1995, Page 19
} 
From the base case face width of 1,050 feet (320 m), the initial approximate $19 \%$ increase in width to 1,250 feet $(381 \mathrm{~m})$ will result in an $8.1 \%$ increase in productivity, thereby decreasing the retreat rate of the face by $10 \%$. The increase in face width by $52 \%$ to 1,600 feet $(488 \mathrm{~m}$ ) leads to a $15.8 \%$ productivity improvement and a $24 \%$ decrease in longwall retreat rate. Multiple time studies were completed to determine the assumptions depicted in Table 1-2. The type of cutting used is bi-directional, meaning a taper cut is completed at the headgate and then a full web cut is completed and cut into the tailgate. The process is then reversed, and a taper cut is completed at the tailgate and a full web cut is mined and cut into the headgate.

Table 1-2: Productivity Improvements - Assumptions: full web cutting of 42 inches; shearer @ $35 \mathrm{fpm}$; shearer at $10 \mathrm{fpm}$ in cut outs; material in place $93.7 \mathrm{lbs} / \mathrm{ft} 3 ; 12 \mathrm{~min}$ for wedge cut ${ }^{6}$.

\begin{tabular}{|l|c||c|c|}
\hline Face width in feet & 1,050 feet $(320 \mathrm{~m})$ & 1,250 feet $(381 \mathrm{~m})$ & 1,600 feet $(488 \mathrm{~m})$ \\
\hline Cycle time per cut in min. & 47 & 52 & 62 \\
\hline Clean Tons per cut & $1,052(956 \mathrm{t})$ & $1,253(1139 \mathrm{t})$ & $1,603(1457 \mathrm{t})$ \\
\hline Raw Tons per min & $27.20(20.34 \mathrm{t} / \mathrm{min})$. & $29.40(21.90 \mathrm{t} / \mathrm{min})$. & $31.5(23.5 \mathrm{t} / \mathrm{min})$. \\
\hline Improvement in \% & & +8.1 & +15.8 \\
\hline
\end{tabular}

During this cutting process, the average shearer cutting speed for full web cuts across the face was determine to be 35 feet per minute $(0.18 \mathrm{~m} / \mathrm{s})$ with peak tram speed of 45 feet per minute $(0.23 \mathrm{~m} / \mathrm{s})$ from headgate to tailgate passes and 55 feet per minute $(0.28 \mathrm{~m} / \mathrm{s})$ on tailgate to headgate passes. The main restriction of headgate to tailgate passes occurs due to the area available under the shearer. When cutting to the tailgate, a bulk of the material is cut by the lead drum that trims the roof and 60 inches $(1.52 \mathrm{~m}$ ) of material below with a cutting or web depth of 42 inches $(1.07 \mathrm{~m})$. The length of the wedge cuts in the headgate area averages about 25 shields or 174 feet $(53 \mathrm{~m})$, and the length of the wedge cuts in the tailgate area averages about 21 shields or 148 feet $(45 \mathrm{~m})$. The average times for the wedge cuts are about 12 minutes. The height of the coal seam is 6.4 feet (2.0

\footnotetext{
${ }^{6}$ Data in Table was obtained gathered by author through time studies and observations.
} 
$\mathrm{m})$ and mining height is a minimum of 7 feet $(2.1 \mathrm{~m})$. The average density of the coal is 84 pounds per cubic foot ( $1346 \mathrm{~kg} /$ cubic $\mathrm{m}$ ), and 150 pounds per cubic foot $(2403 \mathrm{~kg} /$ cubic $\mathrm{m}$ ) for the rock. The overall average density of the material being mined is 93.7 pounds per cubic foot ( $1501 \mathrm{~kg} /$ cubic $\mathrm{m}$ ).

In addition to the productivity gain, one of most significant benefits of wider faces is the reduction of higher cost CM development. Table 1.3 illustrates the benefit of lower $\mathrm{CM}$ gateroad development expected and additional reserve recovery for a defined longwall reserve block size. Based on a reserve district that measures about 10,700 ' by 7,700 ', it will require either six 1,050 foot panels, five 1,250 foot wide panels, or only four 1,600 foot panels. Increasing the face width to 1,250 feet, about $19 \%$, would reduce approximately $14.9 \%$ CM development footage, and increasing the face width to 1,600 feet, about $52 \%$, would save $35.4 \%$ in CM development footage.

The reserve recovery would improve by increasing the face width to 1,250 feet, by 353,723 tons or approximately $1.8 \%$, and increasing the face width to 1,600 feet, would improve reserve recovery by 689,293 tons or $3.5 \%$.

Table 1-3: Panel Design for a District Comparison - Assumptions: Gate-road is 3 entry development with overall with of 200 feet and 166 feet crosscut centers; bleeders are 4 entry development with overall width of 200 feet and 200 feet crosscut centers; mining height of longwall 7.5 feet and CM development is 8 feet; Coal height is 6.4 feet, barrier for mains development is 500 feet $^{7}$.

\begin{tabular}{|l|c|c|c|}
\hline \multicolumn{3}{|c|}{ Longwall Reserve Block of 10,700 feet $x ~ 7,700$ feet } \\
\hline Face width in feet & 1,050 feet $(320 \mathrm{~m})$ & 1,250 feet $(381 \mathrm{~m})$ & 1,600 feet $(488 \mathrm{~m})$ \\
\hline Number of panels & 6 & 5 & 4 \\
\hline $\begin{array}{l}\text { Total footage of gate-road and } \\
\text { bleeder development in feet }\end{array}$ & 435,990 & 379,310 & 321,920 \\
\hline $\begin{array}{l}\text { Development reduction in \% vs. } \\
1,050 \text { feet panel }\end{array}$ & & & 35.4 \\
\hline Reserve in clean tons & $19,632,147$ & $19,985,870$ & $20,321,440$ \\
\hline $\begin{array}{l}\text { Additional clean tons vs. 1,050 feet } \\
\text { panel }\end{array}$ & & 353,723 & 689,293 \\
\hline
\end{tabular}

\footnotetext{
${ }^{7}$ Data in Table was gathered and obtained by author through calculations.
} 
The construction work associated with development and retreat is also reduced. This reduced construction work for development saves time and expenses includes the cutting of overcasts, building of ventilation controls, installation of a belt system, installation of a section power circuit, and track installation. The construction work associated with the slower longwall retreat also saves time and expenses related to belt removal, power moves, track recovery, tailgate and headgate support, and reduced longwall moves.

The initial capital expenditures for widening a longwall face would increase; however, the total capital spending in the long term is similar because the wider panels retreat at a slower pace resulting in fewer shield cycles per reserve area as shown in Table 1.4. The shield cycle is the number of times the shield advances during the mining of the panels. For bi-directional cutting, the distance the shield advances during its cycle is governed by the cutting or web depth, which in our case is 42 inches $(1.07 \mathrm{~m})$. The reduced number of shield cycles per reserve area allows subsequent capital purchases to be delayed. The typical cycle life of a properly designed shield is 50,000 cycles.

From a cost and operating prospective, due to the additional clean tons mined, reduction in development cost, and reduced construction cost, the extension of panel width creates additional economic benefits relative to operating cost.

Table 1-4: Panel Design for Shield Cycle Comparison - Assumptions: Effective shearer web depth is 42 inches ${ }^{8}$.

\begin{tabular}{|l|c|c|c|}
\hline \multicolumn{4}{|c|}{ Longwall Reserve Block of $\sim 10,700$ feet $x \sim 7,700$ feet } \\
\hline Face width in feet & 1,050 feet & 1,250 feet & 1,600 feet \\
\hline Number of panels & 6 & 5 & 4 \\
\hline Shield Cycles & 17,142 & 14,286 & 11,429 \\
\hline Reduction in shield cycles & & 2,856 & 5,713 \\
\hline Reduction in \% shield cycles & & 16.66 & 33.33 \\
\hline Reserve in clean tons & $19,632,147$ & $19,985,870$ & $20,321,440$ \\
\hline
\end{tabular}

${ }^{8}$ Data in Table was gathered and obtained by author through calculations. 
CHAPTER 2: DESIGN FACTORS

The current width design of the longwall at the mine at the time of review in 2002 was 1,050 feet $(320 \mathrm{~m})$. The subject mine has an extensive history of longwall mining and mining conditions related to the longwall method of mining. The mine started longwall mining in January 1981. The mine operation completed mining 46 longwall panels at the time of the study at the end of 2002. In 2002, the mine produced 8.59 million tons ( 7.8 million metric tons) raw, and 6.64 million tons (6.04 million metric tons) clean. The mining units consisted of three continuous miner sections and the longwall. Total manpower at the mine was 568 .

The coal is mined from the Pittsburgh No. 8 coal seam with a seam thickness ranging from six to eight feet. The depth of cover for the mine ranged from 500 to 800 feet (153 to $244 \mathrm{~m}$ ), with some occasional overburden peaks of 1,050 feet $(320 \mathrm{~m})$. The seam has a very slight grade dipping to the southeast ranging from 0 to $3 \%$. Methane liberation at the mine was considered moderate to high with a gas content of 180 to 250 cubic feet per ton (5.61 to 7.79 cubic meter/t). The immediate roof of the mine consisted of interbedded shale and rider coals. The main roof consisted of layers of sandy shale and interbedded with layers of limestone. Caving of the roof behind the longwall face has not presented any issues with shield loading. The immediate floor consists of shale and claystone which when exposed to water can present some soft floor issues.

Geological anomalies encounter during mining can vary randomly from localize floor rolls, localized small faults, clay veins, or slicken sided fractures. The general stress field for this mine is 880 pound per square inch $(6,067$ kilonewtons per square meter) for vertical stress, the minimum horizontal stress is 2,180 pound per square inch (15,030 kilonewtons per square meter), and the maximum horizontal stress is 3,080 pound per square inch $(21,240$ kilonewtons per square meter) at a direction of North 70 degrees East.

The typical panel size mined is 1,050 feet $(320 \mathrm{~m})$ width and 10,000 feet in length. The current schedule of the mine allows this panel to be mined within a 6 
to 7 month period. Mining sequence or the preferred direction of mining is East to West or West to East depending on mining North or South panel progression, but always with a left handed face equipment due to horizontal stress issues is preferable.

Gateroad development is three entry, two chain pillar configuration with and overall width of 200 feet $(61 \mathrm{~m})$ center to center of outside entries. The crosscut centers are 166 feet $(50.6 \mathrm{~m})$ with 16 feet $(4.9 \mathrm{~m})$ entry and crosscut widths, leaving rib to rib pillar dimensions of 150 feet $(45.7 \mathrm{~m})$ in length and 84 feet $(25.6 \mathrm{~m})$ in width. The normal mining height is 8 feet $(2.44 \mathrm{~m})$.

Normal primary gateroad roof support consists of three eight foot combination bolts. These eight foot $(2.44 \mathrm{~m})$ combination bolts are two piece (four foot or $1.22 \mathrm{~m}$ sections) that are 0.804 inch diameter $(20.4 \mathrm{~mm})$ joined with a high strength coupler. The bolts are installed with four feet $(1.22 \mathrm{~m})$ of resin above the coupler. The two outer bolts are installed on 106 inch $(2.69 \mathrm{~m})$ centers on development in a T-3 steel channel from the onboard mounted bolter on the continuous miner with rows every four feet $(1.22 \mathrm{~m})$. The center bolt is install in the channel after the continuous miner is moved to the next mining sequence location. In abnormal roof conditions, wire mesh is installed and bolting is later supplemented by the center bolter with 12 foot $(3.66 \mathrm{~m})$ cable bolts.

Supplemental support is installed in the intersections on development with five rows of 12 foot $(3.66 \mathrm{~m})$ cable bolts totaling 15 bolts with four foot $(1.22 \mathrm{~m})$ between rows, three bolts across the entry.

Pumpable crib supports are used for secondary support in the gateroad and bleeder entries. In the gateroad, the subsequent tailgate entry is supported a with single row of 30 inch $(0.76 \mathrm{~m})$ diameter pumpable cribs with an 8 foot (2.44 $\mathrm{m})$ edge to edge spacing. If the cover exceeds 800 feet $(244 \mathrm{~m})$, then a double row of support is installed. The middle entry of the gateroad is supported with a single row of pumpable cribs with a 10 foot $(3.05 \mathrm{~m})$ edge to edge spacing. This entry is maintained for ventilation purposes only, and not for travel, also if the cover exceeds 800 feet $(244 \mathrm{~m})$, then a double row of support is installed. 
The bleeder entries consist of two - two entry yield pillar systems separated by a 100 foot $(30.5 \mathrm{~m})$ barrier. The primary support in the bleeder system is the same as in the gateroad consisting of three eight foot combination bolts with a T-3 steel channel. The supplemental support in the bleeder entries varies depending upon the purpose or use of the entry. The bleeder entries are number 1 thru 4, number 1 is the set up entry, the number 2 entry is the entry behind the set-up entry used for hauling shields during set up, the number 3 entry is the internal bleeder system entry, and the number 4 entry is the walkable bleeder entry. After the primary support is installed, the set up entry is supplemental bolted with 12 foot $(3.66 \mathrm{~m})$ cable bolts along the entire length of entry prior to slabbing. Truss bolts are installed in drive notch areas that are 30 feet $(9.14 \mathrm{~m})$ in width. After the entry is slabbed to 26 feet in width, scope holes are drill for monitoring and additional support possibly including polyurethane injection is completed as conditions dictate. The supplemental support installed in the entry behind the set up face consists of additional cable bolts in the intersections. This entry remains open to allow travel with shield hauler scoops during set up. The number 3 entry is supported with a single row of pumpable cribs on 10 foot edge to edge spacing along the entire length. The number 4 entry or walk-able bleeder entry consist of a double row of pumpable cribs that are spaced 8 feet $(2.44 \mathrm{~m})$ edge to edge with 4 feet $(1.22 \mathrm{~m})$ between rows.

The longwall face equipment at the mine consisted of a complete Caterpillar system, except for the shearer. The face shield supports were 6.75 feet $(2.058 \mathrm{~m})$ two leg shields with a support capacity rating during normal set pressure of 790 tons (716 t), and a maximum support capacity at yield of 1,096 tons (994 t). The weight of each support is 28.21 tons ( $25 \mathrm{t}$ ). The leg piston diameter is 15 inches $(380 \mathrm{~mm})$ with a designed set pressure of 4,495 psi (310 bar) and a yield pressure of 6,235 psi (430 bar). The collapse height of the shield is 51 inches $(1.3 \mathrm{~m})$ and maximum extended height is 106 inches $(2.69 \mathrm{~m})$. The gate shields for the system are 5.74 feet $(1.75 \mathrm{~m})$ two leg shields with a support capacity rating during normal set pressure of 790 tons (716 t), and a 
maximum support capacity at yield of 1,096 tons (994t), same as the line shields. The weight of each support is 25.7 tons ( $23 \mathrm{t}$ ). The leg piston diameter is $380 \mathrm{~mm}$ ( 15 inches) with a designed set pressure of 4,495 psi (310 bar) and a yield pressure of $6,235 \mathrm{psi}$ (430 bar). The collapse height of the shield is 51 inches $(1.3 \mathrm{~m})$ and maximum extended height is 120 inches $(3.01 \mathrm{~m})$. The mine uses a total of eight gate shields, four at tailgate and four at the headgate. All the shields are electrically hydraulic controlled by Caterpillar PM-4 type controls. The current shield cycle time is eight seconds. The face conveyor is a PF-5 model and is rated at 3,500 tons per hour ( 3,175 metric tonne per hour) with a width of $1,142 \mathrm{~mm}$ (45 inches). The face conveyor is powered by three 1,250 horsepower motors $(932.5 \mathrm{~kW})$. Two of the motors are located at the head drive and the third motor is located at the tail drive. The three face conveyor motors are controlled by the use of Control Start Transmissions (CST's) manufactured by Dodge and programmable logic controllers (PLC's). The CST's contain electrically controlled wet clutches that allow the required pressure to engage the clutches to the desired setting to load share. The PLC's continually monitor and adjust the units as needed to obtain optimum load sharing. The CST's and PLC's also allow the face conveyor motors to start under a "no load" situation. The current longwall faces at the time of the study use two model KP-45 series CST gearbox and one P-45 series CST gearboxes. The speed of the conveyor at normal operation is 353 feet per minute $(1.79 \mathrm{~m} / \mathrm{s})$. The face conveyor is equipped with a $42 \mathrm{~mm}$ (1.65 inches) twin inboard chain conveyor. The stageloader is a PF-5 model type with a width of $1,532 \mathrm{~mm}$ (60.3 inches). The chain conveying the material on the stageloader is a $38 \mathrm{~mm}$ (1.5 inches) chain operating at of speed of 416 feet per minute $(2.11 \mathrm{~m} / \mathrm{s})$, and driven by a 350 horsepower ( $257.4 \mathrm{~kW})$ motor. The stage loader is also equipped with a top mounted crusher driven by a 400 horsepower motor. The crusher is adjustable in two inch increments, but is usually maintained as high as possible for flow through to match the 3500 tons per hour ( $3175 \mathrm{t} / \mathrm{hr}$ ) of the face conveyor. The shearer is a Joy $7 \mathrm{LS} 02$ model, dual drum ranging arm. The shearer is equipped 
with two 60 inch $(1.52 \mathrm{~m})$ drums with a web cutting depth of 42 inches $(1.07 \mathrm{~m})$. The cutting motors are both 700 horsepower $(515 \mathrm{~kW})$, and both traction motors are 50 horsepower variable frequency AC (alternating current) powered. The onboard pump motor to control the hydraulic system is 60 horsepower. The hydraulic pumping system consist of four 100 gallon per minute (375 liter per minute) Kamat pumps with a 500 gallon reservoir tank with a designed operating pressure of 5,000 psi (345 bar). The electrical system for the longwall uses two power centers. The first power center is $3,400 \mathrm{KVA}$ and controls the hydraulic pump system, 120 volt control circuits, both master controls at headgate. The master controls at headgate maintain power to lighting, shield electrical hydraulics, methane sensors, and other control circuits. The second power center is a 7,000 KVA power center with a primary voltage of 4,160 volts and powers the face equipment including the face conveyor drives, the shear, the stageloader, mobile tailpiece, etc. Figure 2.1 is a photo of the face equipment during compatibility testing. All power cables and hoses are routed to the longwall face by use of a monorail system.

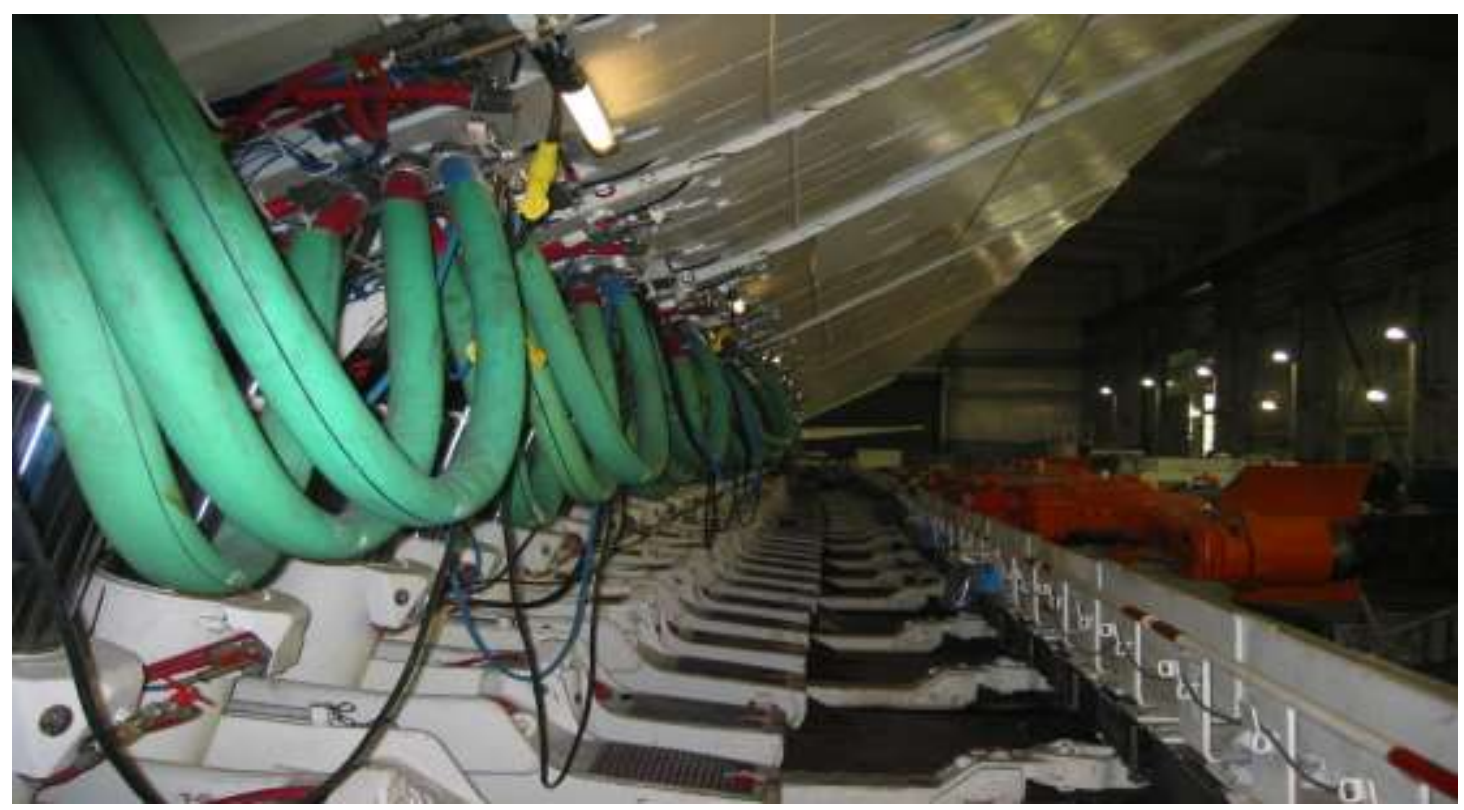

Figure 2-1: Face equipment testing during compatibility in manufacturer's shop ${ }^{9}$

\footnotetext{
${ }_{9}^{9}$ Photo was taken during compatibility testing.
} 
As mentioned, there are extensive benefits to extending longwall mining face width. In order to evaluate the effects of widening the face, the longwall equipment previously discussed as well as mining conditions will need to be reviewed and evaluated for required changes. The major factors to review to increase the face width are:

\subsection{Armored Face Conveyor}

2.2 Hydraulic System

\subsection{Electric System}

\subsection{Rock Mechanics}

2.5 Ventilation and Degasification

2.6 Mine and System Infrastructure

\subsection{Armored Face Conveyor}

One of the biggest equipment considerations was the design of the armored face conveyor (AFC). The horsepower requirements on the wider face would push the limits of the newest technology. In order to calculate the requirements for the $\mathrm{AFC}$, the following information was gathered and used for calculations. The volume capacity of the current 1,142 mm (45 inches) conveyor pan is 3,500 tons $(3,181 \mathrm{t})$ per hour. The shearing machine speed was kept constant at 55 feet per minute $(0.28 \mathrm{~m} / \mathrm{s})$ from the head gate to the tailgate and 42 feet per minute $(0.21 \mathrm{~m} / \mathrm{s})$ from the tail gate to the head gate for horsepower and face conveyor loading. The constant speed of the shearer would be the worst case assumption. Typically when mining across the face there are minor delays for face adjustments, conditions, etc. After multiple time studies, the average shearer speed for production purposes was more in the range of 35 to $36 \mathrm{fpm}(0.177$ to $0.182 \mathrm{~m} / \mathrm{s})$. The speed of the AFC for a $42 \mathrm{~mm}$ (1.65 inches) chain was specified by the manufacturer to be $353 \mathrm{fpm}(1.79 \mathrm{~m} / \mathrm{s})$, and the speed of the AFC for the $48 \mathrm{~mm}$ ( 1.89 inches) chain was specified by the manufacturer to be $370 \mathrm{fpm}(1.88 \mathrm{~m} / \mathrm{s})$. The difference in chain speed is a result of the sprocket design relating back to the geometry of the number of teeth required. 
The web depth of cut created by the shearer is 42 inches $(1.07 \mathrm{~m})$. The cutting height of the seam was 7.5 feet $(2.29 \mathrm{~m})$, with an in-place density of $93.7 \mathrm{lbs} / \mathrm{ft}^{3}$ $\left(1,501 \mathrm{~kg}\right.$ ton per cubic meter) and a broke/loose density of $63.0 \mathrm{lbs} / \mathrm{ft}^{3}(1,009 \mathrm{~kg}$ per cubic meter). The minimum allowable design chain safety factor recommended by the manufacturer is 1.5. The motor breakdown torque for Controlled Start Transmission (CST) units currently used is 2.4. The motor breakdown torque is the maximum torque a motor can produce without abruptly losing motor speed. The gearbox ratio for the CST provided by the manufacturer is 33.32 to 1 . The drive efficiency factor determined by the manufacturer is $79 \%$. The diameter of the sprocket is 2.16 feet $(658 \mathrm{~mm})$ for the 1.65 inches $(42 \mathrm{~mm})$ chain, and 2.26 feet $(689 \mathrm{~mm})$ for the 1.89 inches $(48 \mathrm{~mm})$ chain. The use of the correct friction factors is important for all face conveyor calculations; however, the safety friction factors become more critical on wider faces. In order to obtain accurate friction factors, extensive monitoring of the face conveyor was done over a period of time. Through a process of measurements, historical experience, back calculations, based on the current horsepower on existing faces, friction factors were obtained by the equipment manufacturer. Three friction factors were obtained for different conditions. For the top strand of face conveyor chain, steel on steel contact was determined to be 0.30 , and for coal on steel contact 0.38 . For the bottom strand of face conveyor chain, the friction factor was determined to be 0.40 . The weight of the chain and flights for a 42 $\mathrm{mm}$ (1.65 inches) installation is $80 \mathrm{lbs} / \mathrm{ft}^{3}$ (1282 kg per cubic meter), and for a 48 $\mathrm{mm}$ installation the weight is $107 \mathrm{lbs} / \mathrm{ft}^{3}$ (1714 $\mathrm{kg}$ per cubic meter). The drive motor speed for the installation is 1770 revolutions per minutes (RPM). The fluid coupling inefficiency factor provided by the manufacture to determine slip was $2 \%$, leaving $98 \%$ efficiency. The curve factor is provided by the manufacturer for the drive unit. Through field observations and calculations it was determined that the recirculation through the bottom strand is approximately $2 \%$. The chain is double strand. The test strength of the $42 \mathrm{~mm}$ (1.65 inches) chain is 202 tons (183 t), and the test strength of the $48 \mathrm{~mm}$ (1.89 inches) chain is 245 tons (222 $\mathrm{t}$ ). 
The breaking strength of the $42 \mathrm{~mm}$ (1.65 inches) chain is 276 tons (250 t), and the breaking strength of the $48 \mathrm{~mm}$ (1.89 inches) chain is 325 tons (294 t).

After gathering this information, and reviewing observations from existing systems that perform well, some of the key factors from calculations are displayed in the information in Table 2.1 for the three different face widths.

Table 2-1: Armored Face Conveyor design calculations; $\mathrm{H}$ - headgate, $\mathrm{T}$ - tailgate; volume capacity of the AFC is approximately 3500 tons per hour ${ }^{10}$

\begin{tabular}{|c|c|c|c|c|c|c|}
\hline Face Width & \multicolumn{2}{|c|}{1,050 feet $(320 \mathrm{~m})$} & \multicolumn{2}{|c|}{1,250 feet $(381 \mathrm{~m})$} & \multicolumn{2}{|c|}{1,600 feet $(488 \mathrm{~m})$} \\
\hline Chain Size & \multicolumn{2}{|c|}{$2 \times 42 \mathrm{~mm}$} & \multicolumn{2}{|c|}{$2 \times 42 \mathrm{~mm}$} & \multicolumn{2}{|c|}{$2 \times 48 \mathrm{~mm}$} \\
\hline $\begin{array}{l}\text { Chain Safety } \\
\text { Factor (min. 1.5) }\end{array}$ & \multicolumn{2}{|c|}{1.66} & \multicolumn{2}{|c|}{1.66} & \multicolumn{2}{|c|}{1.55} \\
\hline Horsepower & \multicolumn{2}{|c|}{$3 \times 1,250$} & \multicolumn{2}{|c|}{$3 \times 1,250$} & \multicolumn{2}{|c|}{$3 \times 1,650$} \\
\hline Cutting Direction & $H>T$ & $\mathbf{T}>\mathrm{H}$ & $H>T$ & $\mathbf{T}>\mathrm{H}$ & $\mathrm{H}>\mathrm{T}$ & $\mathbf{T}>\mathrm{H}$ \\
\hline $\begin{array}{l}\text { AFC Max. } \\
\text { loading rate in } \\
\text { Short tons per } \\
\text { hour }\end{array}$ & 3,512 & 3,517 & 3,512 & 3,517 & 3,533 & 3,496 \\
\hline Reserve in \% & 30 & 35.6 & 16.6 & 23.3 & 10.0 & 16.8 \\
\hline
\end{tabular}

The 1,650 horsepower $(1,214 \mathrm{~kW})$ requirements made it necessary to investigate fluid couplings, CST, and variable frequency motors (VFD) for the drives to minimize risk and increase reliability and performance. After reviewing the initial design of the fluid coupling option, the drive design was eliminated because of the size of the unit was prohibitive. Most of the newer technology wider faces use is the CST 45 series gearbox with 4,160 volt armored face conveyor motors and control programming during startup and operating. The 1,600 foot $(488 \mathrm{~m}$ ) face requires a CST 65 series gearbox, which was not used in the US. The CST 65 series gearbox, which is an enlarged version of the current 45 series gearbox, is being used in Germany. The VFD and the CST options

\footnotetext{
${ }^{10}$ Data in Table was calculated by author through data gathered from equipment manufacture and field data.
} 
would provide soft startup, load sharing, overload protection, and creep speeds. The VFD also could dampen the chain vibration. The VFD motor was not yet available in the 1,650 horsepower $(1,214 \mathrm{KW})$ range, and the VFD system has not been proven reliable in this class. Considerations for VFD also had to be given for the total harmonic distortion and the impact to the cables, ground faults, data transmission, and communication system. The VFD would permit smaller sized units, an advantage for tip to face distances. The best feature of the VFD is that AFC chain speed can be varied. Currently, this is not a benefit in most mines in the United States because belt haulage systems are usually designed with excess capacity. Due to familiarity and experience with the CST's, the decision was made to use CST's for the wider faces.

Based on the results in Table 2.1, initial concerns arose about the amount of reserve capacity horsepower (10\%) for the headgate to tailgate pass during mining for the 1,600 feet $(488 \mathrm{~m})$ face width. The use of high strength steel in a $42 \mathrm{~mm}$ (1.65 inches) chain was discussed with chain manufacturers to provide the same strength as the $48 \mathrm{~mm}$ (1.89 inches) chain. The use of the $42 \mathrm{~mm}(1.65$ inches) high strength chain links will reduce the weight of the chain by $30 \%$, which would reduce the horsepower requirements. The new $42 \mathrm{~mm}$ (1.65 inches) chain had not been used anywhere and was not proven technology and raised concern about its reliability. The use of $48 \mathrm{~mm}$ (1.89 inches) chain appeared to be the best solution, the wear and reliability of the $48 \mathrm{~mm}$ (1.89 inches) chain appeared to be adequate for the wider face, as some mines in the coal industry were already using the chain with success. After discussions with these mines, concerns with handling of the heavier chain during moves for installation and maintenance for wear and connector links, the concerns were resolved.

The issue of reserve capacity horsepower still needed further review. A study was schedule to measure the loading of the AFC for a "high production day" (approximately 10,000 raw tons (9,090 t) mined per shift) was monitored to evaluate the concerns for reserve capacity horsepower for the headgate to tailgate pass during mining for the 1,600 feet $(488 \mathrm{~m})$ face width. Figure 2.2 
shows the results of loading of the face conveyor for a 24 hour period for a three eight hour production shifts with workers changing out at the face. The data was gathered by measuring the face conveyor motor currents. The face width monitored was 1,250 feet (381 m) panel width, with three 1,250 horsepower (919 $\mathrm{kW}$ ) motors using CST technology, $42 \mathrm{~mm}$ (1.65 inches) chain, and AFC width of $1142 \mathrm{~mm}$ (45 inches). The graph depicts that rarely is the conveyor loaded more than $76 \%$ of the rated capacity in load during operation. The most frequent occurrence of loading occurs at $18 \%$ of the rated capacity in load about $11 \%$ of the time. The calculations completed in Table 2.1 were based on the conveyor being fully loaded, with the information developed in Figure 2.2, the issue of reserve capacity horsepower for the headgate to tailgate pass during mining for the 1,600 feet $(488 \mathrm{~m})$ face width is minimal. Another method to mitigate the reserve capacity horsepower concern, if necessary, is to limit the speed of the shearer electronically as the shearer travels toward the tailgate.

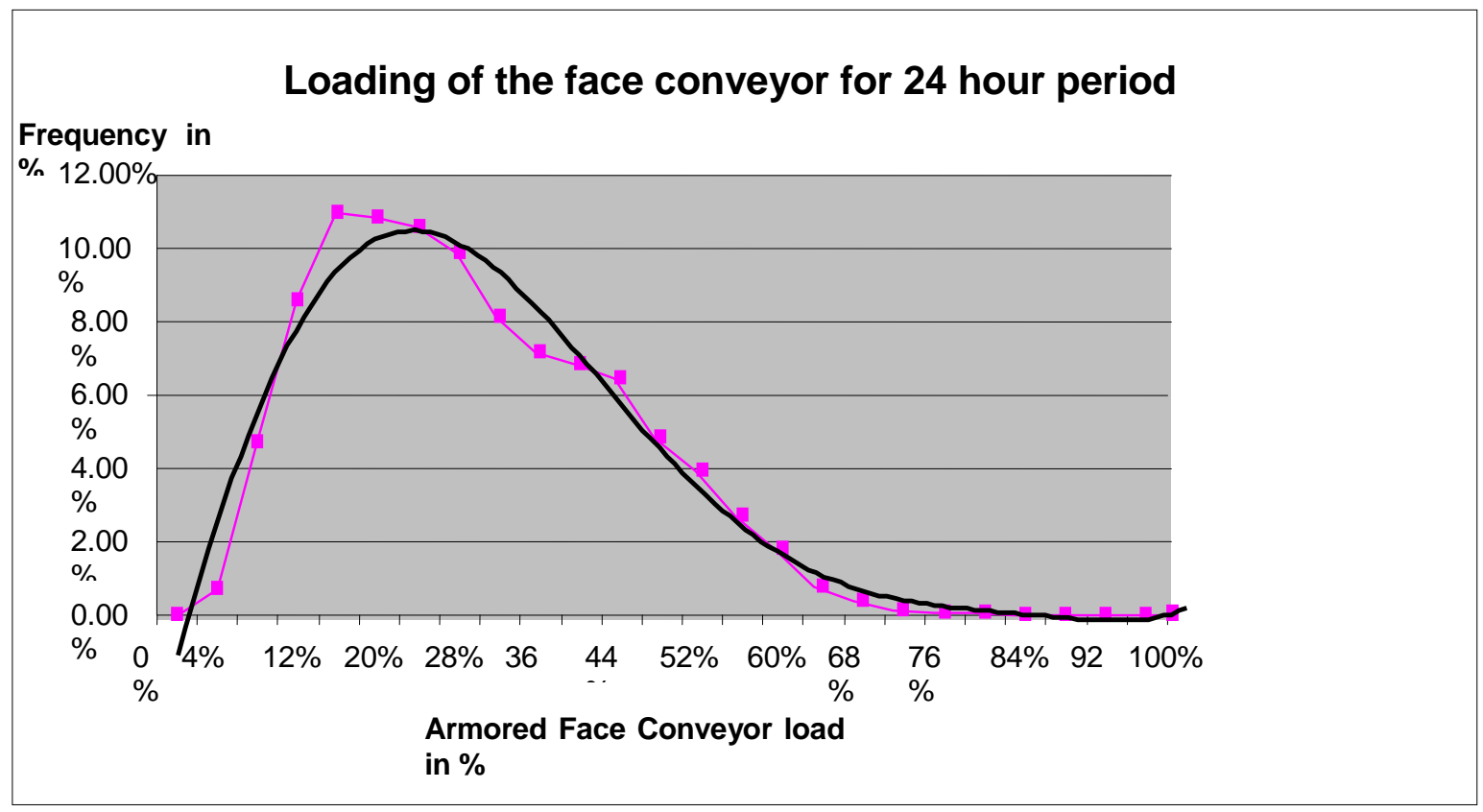

Figure 2-2: Measurement Data from Loading of Armored Face Conveyor - Assumptions: full web cutting of 42 inches; cutting height of 7.5 feet; material density in place $93.7 \mathrm{lbs} / \mathrm{ft} 3$; material density broken $63.0 \mathrm{lbs} / \mathrm{ft} 3 ; \mathrm{V}$ max < 3500 tph of AFC; Minimum allowable chain S.F. 1.5;Motor Breakdown torque - 2.4; Friction factors are 0.38/0.3/0.4; conveyor width $1142 \mathrm{~mm}^{11}$.

${ }^{11}$ Data in Figure was calculated by author through data gathered from equipment manufacture and field data. 


\subsection{Hydraulic System}

The additional system pressure losses due to the additional face width, the adequacy of the monorail system due to the additional weight and lines, and the pump system setup and move requirements were investigated. A minimum of two shields are required to move at the same time to keep up with the shearer cutting rate. The movement of two shields with a flow rate of about 80 gallons or 365 liters per shield will allow the face to keep up with shearer maximum cutting rates of 60 feet per minute $(0.31 \mathrm{~m} / \mathrm{s})$ and approximate an 8 second shield cycle time. As a result, a total flow rate of 160 gallons per minute or 730 liters per minute are required for the shield advancement, which is an average flow of 400 liters per minute. Minimum set pressure for the shields based on shield design and monitoring was established at 4060 psi (280 bar).

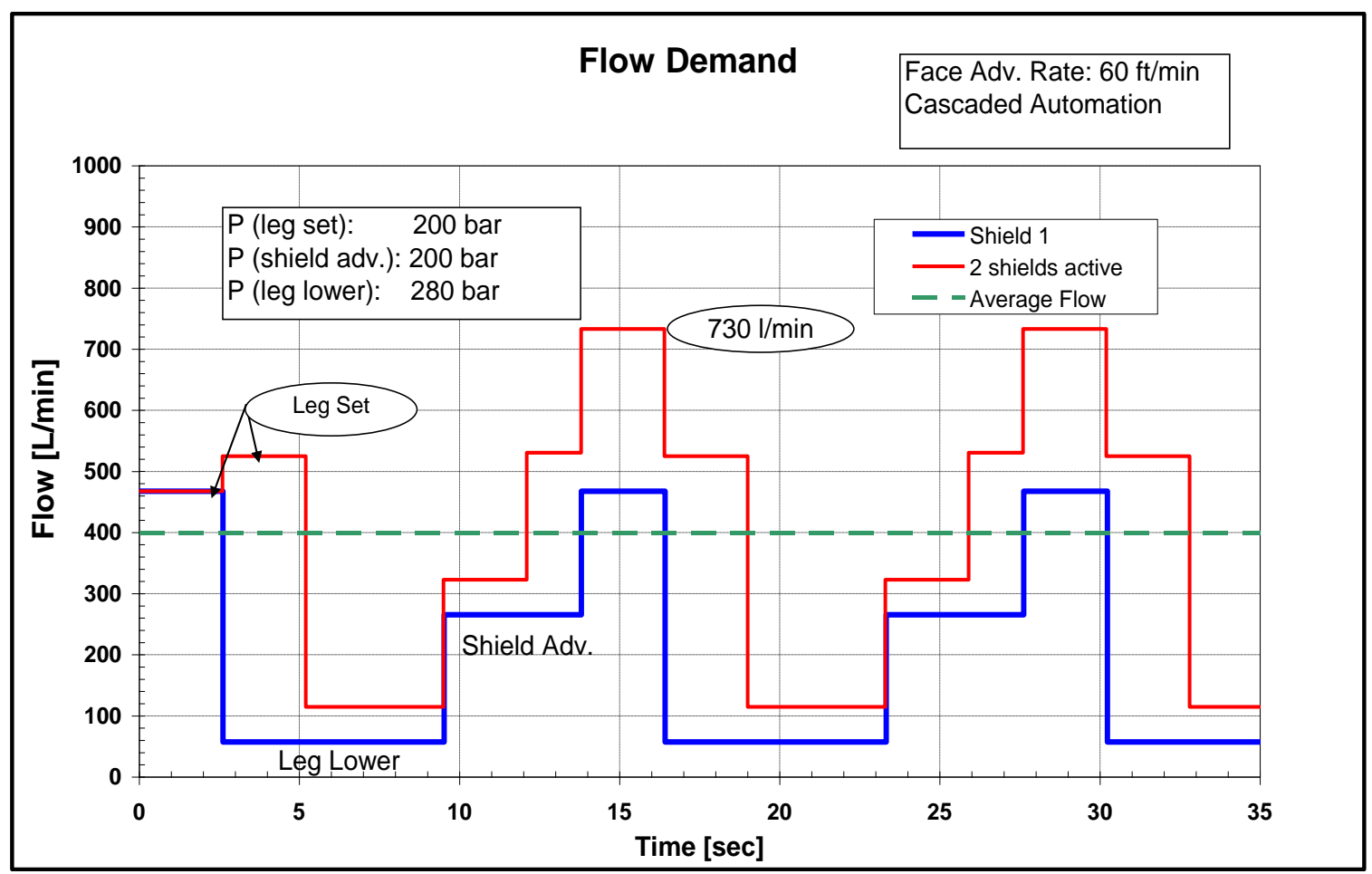

Figure 2-3: Flow Demand for Pressures Calculations - Maximum shearer speed of $60 \mathrm{fpm}$ based on $\mathrm{V}$ max $<3500$ tph of AFC; Two shield will be moved in cascaded automation ${ }^{12}$.

${ }^{12}$ Data in Figure was gathered by author through discussions with equipment manufacture. 
Several calculations were completed for face widths of 1,050 feet (320 m), 1250 feet $(381 \mathrm{~m})$, and 1600 feet $(488 \mathrm{~m})$. The calculations were completed with the use of the shield manufacturer's software program. This program requires input of all line sizes, fittings, valve banks, etc. to obtain accurate results. Based on lab testing results of fittings, valve banks, hoses, the friction/loss factors are input into the program to calculate the losses. The program is proprietary software of the manufacturer. The calculations were completed, one case with two shields being cycled at the tailgate and a second case with two shields being cycled past mid-face. The current hydraulic system, Figure 2-4, consist of two high pressure 2 inch $(50 \mathrm{~mm}$ ) hoses along the AFC for high pressure feeds, and two 2.5 inch $(60 \mathrm{~mm})$

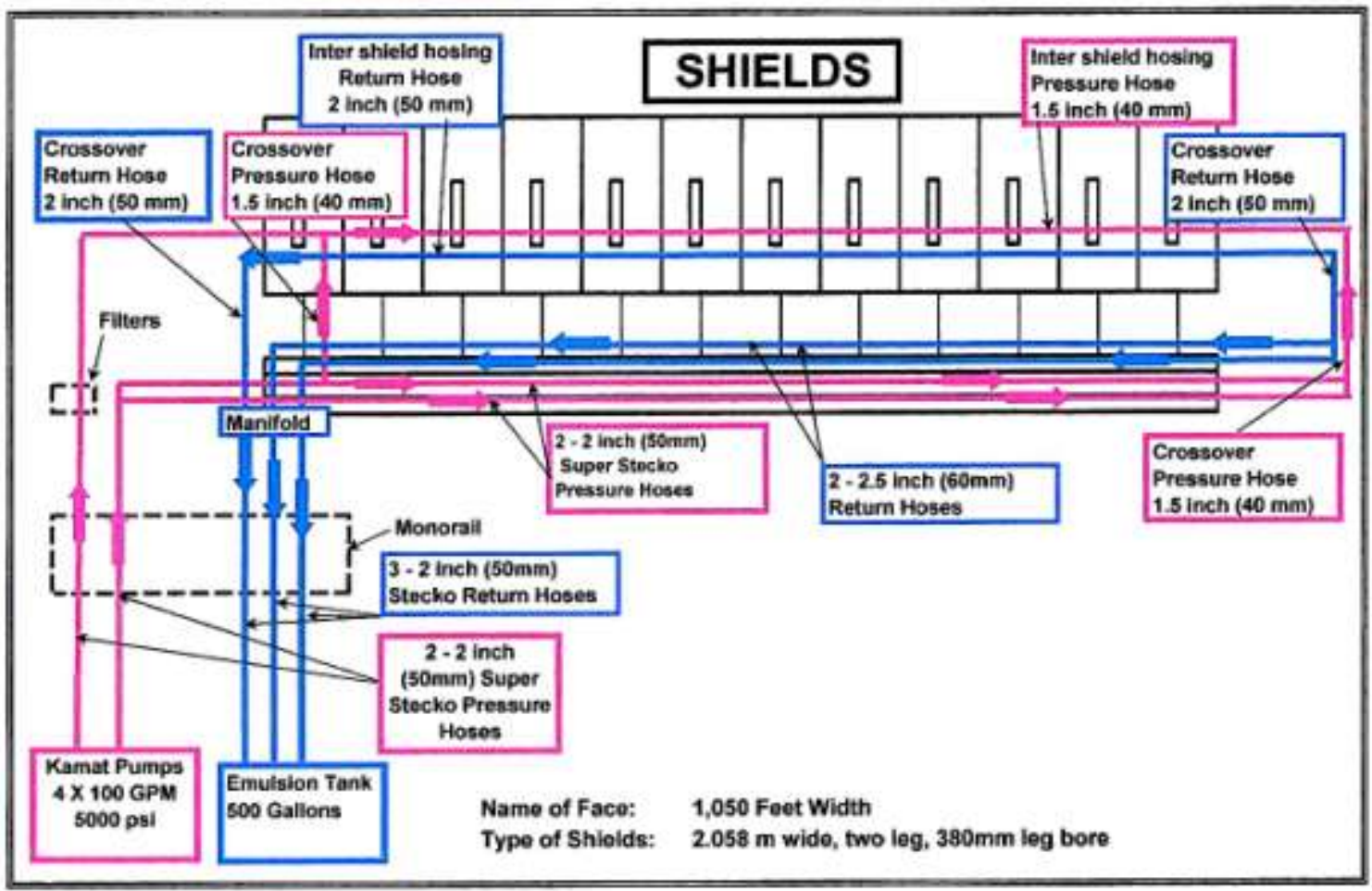

Figure 2-4: Hydraulic Schematic of 1,050 feet wide longwall base case ${ }^{13}$. hoses along the AFC for the return feeds. The inter-shield hoses for the high pressure is 1.5 inch $(40 \mathrm{~mm})$, and the return inter-shield hoses are 2 inch (50 $\mathrm{mm}$ ). The current hydraulic system contains no crossovers other than at the

\footnotetext{
${ }^{13}$ Data in Figure was gathered by author through discussions with equipment manufacture.
} 
headgate and tailgate only to connect the AFC and inter-shield hoses. The mine had a history of bad experience with maintenance issues and safety concerns dealing with crossovers along the face, and as a result did not use crossovers in the face area of the hydraulic system. Hosing from the longwall stageloader to the pump station consisting of two high pressure 2 inch $(50 \mathrm{~mm})$ hoses and three 2 inch $(50 \mathrm{~mm}$ ) return hoses. The worst case scenario for pressure loss occurs with the two shields being cycled past mid-face due to the lack of crossovers. The Table 2-2 provides a summary of the details of the hydraulic system hosing attributed to the increase in face width.

Table 2-2: Details of the hydraulic system hosing ${ }^{14}$

\begin{tabular}{|c|c|c|c|c|}
\hline \multicolumn{2}{|c|}{ Lonqwall Face Width } & 1,050 feet & 1,250 feet & 1,600 feet \\
\hline \multirow[t]{4}{*}{ Inter- Shield Hosing } & High Pressure \# of hoses & \multicolumn{3}{|c|}{1} \\
\hline & Diameter mm (inch) & \multicolumn{3}{|c|}{ DN $40(1.5)$} \\
\hline & Return \# of hoses & \multicolumn{3}{|c|}{1} \\
\hline & Diameter mm (inch) & \multicolumn{3}{|c|}{ DN 50 (2) } \\
\hline \multirow[t]{2}{*}{ High pressure } & Number hose monorail /AFC & $2 / 2$ & $3 / 2$ & $3 / 2$ \\
\hline & Diameter mm (inch) & \multicolumn{3}{|c|}{ DN 50 (2) } \\
\hline \multirow[t]{3}{*}{ Return } & Number hose monorail / AFC & $3 / 2$ & $4 / 2$ & $4 / 2$ \\
\hline & Monorail Diameter mm (inch) & \multicolumn{3}{|c|}{ DN $50(2)$} \\
\hline & AFC Diameter mm (inch) & \multicolumn{3}{|c|}{ DN $60(2.5)$} \\
\hline \multirow[t]{2}{*}{$\begin{array}{l}\text { Number of crossover } \\
\text { In the face }\end{array}$} & \begin{tabular}{|l} 
High pressure DN 40 \\
$\left(1.5^{\prime \prime}\right)$
\end{tabular} & 2 & 2 & 5 \\
\hline & Return DN 50 mm (2"') & 2 & 2 & 5 \\
\hline
\end{tabular}

Calculations based on this system resulted in an increase of

approximately 72.5 psi or 5 bar pressure loss from 1,050 feet $(320 \mathrm{~m}$ ) to 1,250 feet $(381 \mathrm{~m})$ wider face. In order to overcome this pressure loss, one 2 inch (50 $\mathrm{mm}$ ) high pressure hose and one 2 inch $(50 \mathrm{~mm}$ ) return hose was added to the monorail and longwall stageloader system. The addition of these hoses reduced the pressure loss by almost 130 psi or 9 bar, an improvement of 58 psi or 4 bar over the original face design of 1,050 feet $(320 \mathrm{~m})$. Further calculations were completed to obtain the additional pressure drop to increase the face width to 1,600 feet $(488 \mathrm{~m})$. Increasing the face width by another 350 feet $(107 \mathrm{~m})$ to a 
total longwall face width of 1,600 feet $(488 \mathrm{~m})$ resulted in a pressure drop of approximately 145 psi or 10 bar. As previously mentioned, the face hydraulic design did not include crossovers. Additional crossovers will be necessary along the face to overcome the pressure loss from the additional face width, but the existing type 1.5 inch or $40 \mathrm{~mm}$ pressure lines and 2 inch or $50 \mathrm{~mm}$ return lines will be adequate for the crossover designs. The crossovers will be placed at one quarter of the way down the face, halfway down the face, and three quarters of the way down the face, with the original connection at the headgate and tailgate being maintained. The addition of the crossovers in the system design improved the hydraulic circuit by almost 290 psi or 20 bars when comparing the 1,250 feet $(381 \mathrm{~m})$ face system. The combination of both changes from the original 1,050 feet $(320 \mathrm{~m}$ ) face system yielded a 203 psi and 14 bars improvement.

Table 2-3: Pressures Loss Calculations for increased face length ${ }^{15}$

\begin{tabular}{|l||c|c||c|}
\hline \multicolumn{1}{|c||}{ Longwall Face Width } & 1,050 feet & 1,250 feet & 1,600 feet \\
\hline Shearer speed and shields moving at the same time & 60 feet per minute / two shields \\
\hline $\begin{array}{l}\text { Pressure drop on the high pressure side due to } \\
\text { additional length in bar (psi) }\end{array}$ & $5(72.5)$ & $10(145)$ \\
\hline Total flow-rate in gpm (l/min) & \multicolumn{2}{|c|}{$190(730)$} \\
\hline Pump capacity available in gallons per minute (Ipm) & \multicolumn{2}{|c|}{$400(1500)$} \\
\hline Number of pumps & 4 \\
\hline
\end{tabular}

As mentioned before, the hydraulic flow for this system was powered by four 100 gallon per minute or 375 liter per minute pumps operating at 5,000 psi or 345 bar. The pumps operate based on demand programming and were recently converted to VFD technology. To meet the minimum design pressure of the 4,060 psi or 280 bar, the minimum operating pressure of the pumps must be maintained at least at 4500 psi or 310 bar. The Table 2-3 provides a summary of the pressure losses attributed to the increase in face width.

\subsection{Electric System}

The increase in face length required the electrical system to be reviewed. The transformer was designed to handle the increased horsepower loads with

${ }^{15}$ Data in Figure was compiled by author while working with shield equipment manufacture's software program. 
considerations for ventilation and power moves. The initial increase in length from $1,050$ feet $(320 \mathrm{~m})$ to 1,250 feet ( $381 \mathrm{~m})$, required no changes to the current electrical system. The \#2 cable to the face conveyor motors was adequate to handle the additional starting current, and the current 3,400 KVA and 7,000 KVA transformers were sufficient for motor loads during starting and operation. The increase in length from 1,250 feet (381 m) to 1600 feet $(488 \mathrm{~m})$, will require the increase in size of the face conveyor motor cables from the current \#2 cable to a $2 / 0$ cable due to the additional required horsepower, motor starting current, and distance. Since the system operates on 4160 volts, smaller cable sizes were possible than at lower voltages. Requirements for the ground monitoring systems and potential problems associated with the shearer cable length and the pick up and drop out of the ground monitors were reviewed. Working with the electrical equipment manufacturer, new designed ground monitors were installed to provide required protection. The remaining power cables for the face were adequate. As determined by the face lighting and communication system manufacturer, additional power supplies will be required for the face lighting, communication system, and electrical hydraulic controls for the face at reduced shield spacing intervals to account for the voltage drops over the longer distance. The current operates with a 12 volt system, the manufacturer is looking at a later upgrade to a 24 volt system. The current 3,400 KVA power center will remain the same, while the 7,000 KVA power center will be upgraded and enlarged in length to 9,000 KVA to handle the additional motor load of the face conveyor. This increase will handle the additional 1,200 horsepower ( $883 \mathrm{~kW}$ ) requirement added to the face to power the face conveyor.

As part of this review of electrical system, the entire electrical system for the mine was modeled for the additional loads required during starting up. The modeling indicated the system would be adequate, but alternative time delay motor starting was discussed as options should the in-rush current loads cause excessive voltage drops in the system. This process would involve developing a pattern for the start up of the high horsepower motors on the longwall face in 
sequence to avoid excessive loads. With the CST's, one conveyor motor would start, then sequence to the next conveyor motor start, then to the final conveyor motor start, at which time the shearer would then start. This sequencing was not required because of the mines high quality electric system. The sequencing may be necessary at other mines, but will result in potential production delays due to the required slower start up.

The longwall monorail system was also reviewed. The additional weight of power cables and hydraulic hoses, as a result of the upgrades, were looked at for possible modifications to trolley carriers. A review for the potential use of separate monorail for hydraulic piping system was considered. The current design of the monorail was reviewed. The additional weight of hoses and cables would not effect the operation of the monorail with respect to current bolts used to suspend it, beams to carry the trolleys, or the trolley wheels and support pins. However, the trolleys cable brackets will need to be widened to accommodate the additional cable widths and extra hoses. The use of an additional monorail was a possible solution, if necessary, to separate the electrical and hydraulic systems, but due to the additional work required to install and maintain this extra system, the decision was made to use the existing system with the slight modifications outlined above.

\subsection{Rock Mechanics}

Several factors were reviewed when looking at rock mechanic issues. Additional pillar and shield loading was reviewed. As the gob caves behind the retreating longwall face, caved rock material will pile up behind the shields and take load from the upper strata. The gob pressure around the panel edges is mainly a result of the weight of the caved material. The gob pressure increases toward the center of the panel. This is a result of overburden weight compacting the caved material. The width of the longwall panel determines whether the gob pressure reaches the full load of the overburden weight. Longwall panels that are subcritical do not reach full load of the overburden in the gob. This is because the panel is too narrow and the upper strata remains unbroken and will be bridged by 
the side abutments, resulting in gob pressure being approximately equal to the weight of the rock fragments within the caving height. When the panel reaches critical width and length, then the maximum gob pressure reaches the overburden weight. When the panel exceeds the critical width and length, the panel is then termed as "supercritical". Since the existing face of 1,050 feet $(320 \mathrm{~m})$ is already at supercritical width, as expressed by the formula for "Critical Width", at an overburden depth of $750-800$ feet $(229-244 \mathrm{~m})$ with an angle of draw of $21^{\circ}$, the increased face width would have minimum or no additional loading impact on the shield supports or on the gate entry pillars.

$$
\text { Critical Width }=100+1.048 \text { (overburden depth) }
$$

The additional "stand-time" for the entries were review. Since the wider face would have a slower retreat rate, as shown in Table 1-2, the entries would need to stay open longer. From calculations shown in Table 2-4 and in-mine conditions observed, it was determined that at the worst case of $8.4 \%$ reduction in longwall face advance (approximately 25 days), would have minimal impact to the gate road roof, floors, and pillars due to the additional stand time from the roof or floor pressures created by the opening.

Table 2-4: Change in face advancement ${ }^{16}$.

\begin{tabular}{|l|c||c|c|}
\hline Face width in feet & 1,050 feet (320 m) & 1,250 feet (381 m) & 1,600 feet (488 m) \\
\hline Cycle time per cut in min. & 47 & 52 & 62 \\
\hline $\begin{array}{l}\text { Reduction in cutting rate \% } \\
\text { for advancement }\end{array}$ & -9.6 & -24.2 \\
\hline $\begin{array}{l}\text { Improvement in productivity } \\
\text { due to face width \% }\end{array}$ & & +8.1 & +15.8 \\
\hline $\begin{array}{l}\text { Change in face } \\
\text { advancement }\end{array}$ & $-1.5(-9.6+8.1)$ & $-8.4(-24.2+15.8)$ \\
\hline
\end{tabular}

The same drive units were used on both 1,050 feet $(320 \mathrm{~m})$ and 1,250 feet $(381 \mathrm{~m})$ faces. The extension to the 1600 feet $(488 \mathrm{~m})$ resulted in the need for larger drive units. The current tip to face distance provided by the existing shield design is 18 inches $(457 \mathrm{~mm})$. The larger drive units will cause additional shield tip

\footnotetext{
${ }^{16}$ Data in Table was obtained by author.
} 
to face distance of four inches along the headgate shields and tailgate shields. Four inches will be added to the gate shield canopies to keep the same tip to face distances. This modification to the shields did not affect the integrity or geometry of the shield, and resulted in negligible change to the shields tip pressure. One additional gate shield was needed at the headgate due to the added length of the larger face conveyor drive gearbox. The larger drives did not require any additional headgate width or height for the entry to be mined over the current require 16 feet of width and 8 feet of height.

Considerations had to be made for the effect of the additional weight of the larger AFC drives when soft floor conditions would be encountered. The base plates for the larger drives were extended to accommodate the larger power units to help reduce the additional ground pressure. Table $2-5$ indicates the weight for the larger drives required to extend the face to 1,600 feet $(488 \mathrm{~m})$ width.

Table 2-5: Comparison of weight for drive units ${ }^{17}$.

\begin{tabular}{|l|c||c|c|}
\hline & Weight, tons $(\mathrm{kg})$ & $\begin{array}{c}\text { Weight of power unit, } \\
\text { tons (kg) }\end{array}$ & $\begin{array}{c}\text { Difference in } \\
\text { weight ton (kg) }\end{array}$ \\
\hline $\begin{array}{l}\text { Tailgate drive with no } \\
\text { power units }\end{array}$ & $46.3(42,002)$ & & \\
\hline $\begin{array}{l}\text { Tailgate drive with smaller } \\
\text { power units }\end{array}$ & $62.9(57,016)$ & $16.6(15,014)$ & \\
\hline $\begin{array}{l}\text { Tailgate drive with larger } \\
\text { power units }\end{array}$ & $66.8(60,599)$ & $20.5(18,597)$ & $3.9(3,583)$ \\
\hline $\begin{array}{l}\text { Headgate drive with no } \\
\text { power units }\end{array}$ & $34.3(31,116)$ & & \\
\hline $\begin{array}{l}\text { Headgate drive with } \\
\text { smaller power units }\end{array}$ & $60.5(54,876)$ & $26.2(23,760)$ & \\
\hline $\begin{array}{l}\text { Headgate drive with larger } \\
\text { power units }\end{array}$ & $69.2(62,723)$ & $34.9(31,607)$ & $8.7(7,847)$ \\
\hline
\end{tabular}

The larger power units added about 3.9 tons $(3,583 \mathrm{~kg})$ of weight to the tailgate drive, and add about 8.7 tons $(7,847 \mathrm{~kg})$ to the headgate drive unit. The existing gate shield bases were modified to increase the ram size for the additional force to push the heavier drives. The current cylinders are $165 \mathrm{~mm}$ (6.5 inches) bore with $100 \mathrm{~mm}$ (3.94 inches) rod, the new cylinders were $180 \mathrm{~mm}$ (7.1 inches)

\footnotetext{
${ }^{17}$ Data in Table was obtained by author.
} 
bore with $100 \mathrm{~mm}$ (3.94 inches) rod. At 4,640 psi (320 bar), the current cylinders have a force of 76.8 ton $(678 \mathrm{kN})$ to advance shields and 48.6 ton $(432 \mathrm{kN})$ push drive frame. At 4,640 psi (320 bar), the new cylinders have a force of 91.4 ton $(813 \mathrm{kN})$ to advance the shields and 63.2 ton $(562 \mathrm{kN})$ push the drive frame. With the additional headgate shield added that was previously mentioned, the push force to the headgate drive frame increased by 121.6 tons $(1,082 \mathrm{kN})$ or a $63 \%$, and the push force to the tailgate drive frame increased by 58.4 tons $(520 \mathrm{kN})$ or a $30 \%$. The upgrade enables the additional pushing force to overcome the weight gain for the drives. Clevis connections and relay bars were upgrade to provide adequate strength for cylinder to panline connections.

Other roof control factors were considered during set-up and recovery. In the set-up entry, additional width was required. This additional width was because the new drives required the shields to set back an additional 4 inches $(10.2 \mathrm{~cm})$. The mining width in the set-up notch was enlarged by 6 inches $(15.2 \mathrm{~cm})$ at both the headgate and tailgate areas. Although longwall moves were reduced by the wider face, each move would require additional time to roof bolt the wider face during recovery, and extract the increase number of panline and shield supports. Additional pullout chutes would be needed to improve the ventilation, roof control, and equipment extraction process by allowing quicker access and the use of extra equipment.

\subsection{Ventilation and Degasification}

Ventilation and degasification was another important factor that needed to be assessed. The liberation of methane and the resistance to the ventilating circuit is directly proportional to the width of the face. For an adequate evaluation, a study was conducted to evaluate face liberation. The initial goal was to determine the methane emissions from individual sections of the longwall face and to

extrapolate that data to estimate emissions from a longer longwall face. The current ventilation schematic is shown in Figure 2.5. Using this approach, the face is divided into segments to characterize how methane emission rates vary across 
the face. Face emissions are then predicted from a graphical solution using regression analysis at longer face lengths based on emissions data from shorter faces. This study was a joint industry project with $\mathrm{NIOSH}$, and the software to complete the regression analysis was provided by $\mathrm{NIOSH}$.

The study was conducted at the mine in which coal was mined during three production shifts each day. Continuous methane emission monitoring was limited to one shift for the three days of this study. Continuously recording methane

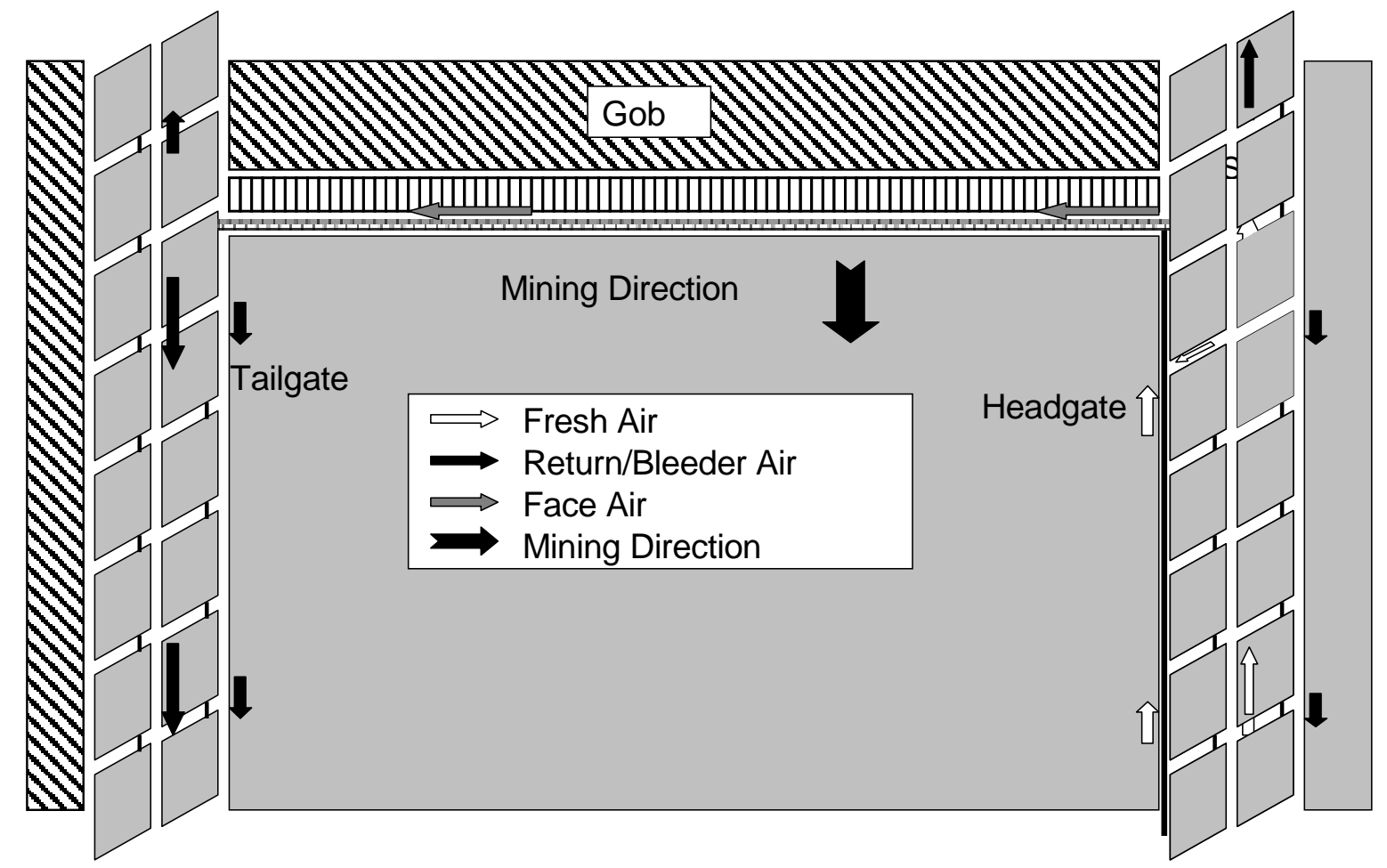

Figure 2-5: Typical longwall face ventilation currently used during study ${ }^{18}$.

monitors were installed on the longwall face. The monitors sampled at five second intervals, and one minute average methane concentrations were recorded by data loggers. Airflow measurements were made at these locations on the face at least once per shift to provide quantities for the calculation of emission rates based on

\footnotetext{
18 "Data Prediction of longwall methane emissions and the associated consequences of increasing longwall face lengths: a case study in the Pittsburgh Coalbed", S.J. Schatzel, R.B. Krog, F. Garcia, and J.K. Marshall, NIOSH, Pittsburgh Research Laboratory, Pittsburgh, PA, USA, J. Trackemas, 2006.
} 
the methane concentration data. A production time study consisting of shearer location on the face and shearer mining direction (head-to-tail or tail-to-head) was also conducted throughout the three days of the face emissions monitoring. The production delays, duration and cause, the face position at the start and end of each shift, the presence of any geologic discontinuities or other conditions encountered along the face, and any other pertinent data or observations were also recorded as part of the time study.

Methane emission rates were determined for each face segment of each pass of the shearer using the associated methane concentration, ventilation airflow, and time study data. The focus of this study was longwall face ventilation and methane emissions, monitors were not positioned near the headgate and

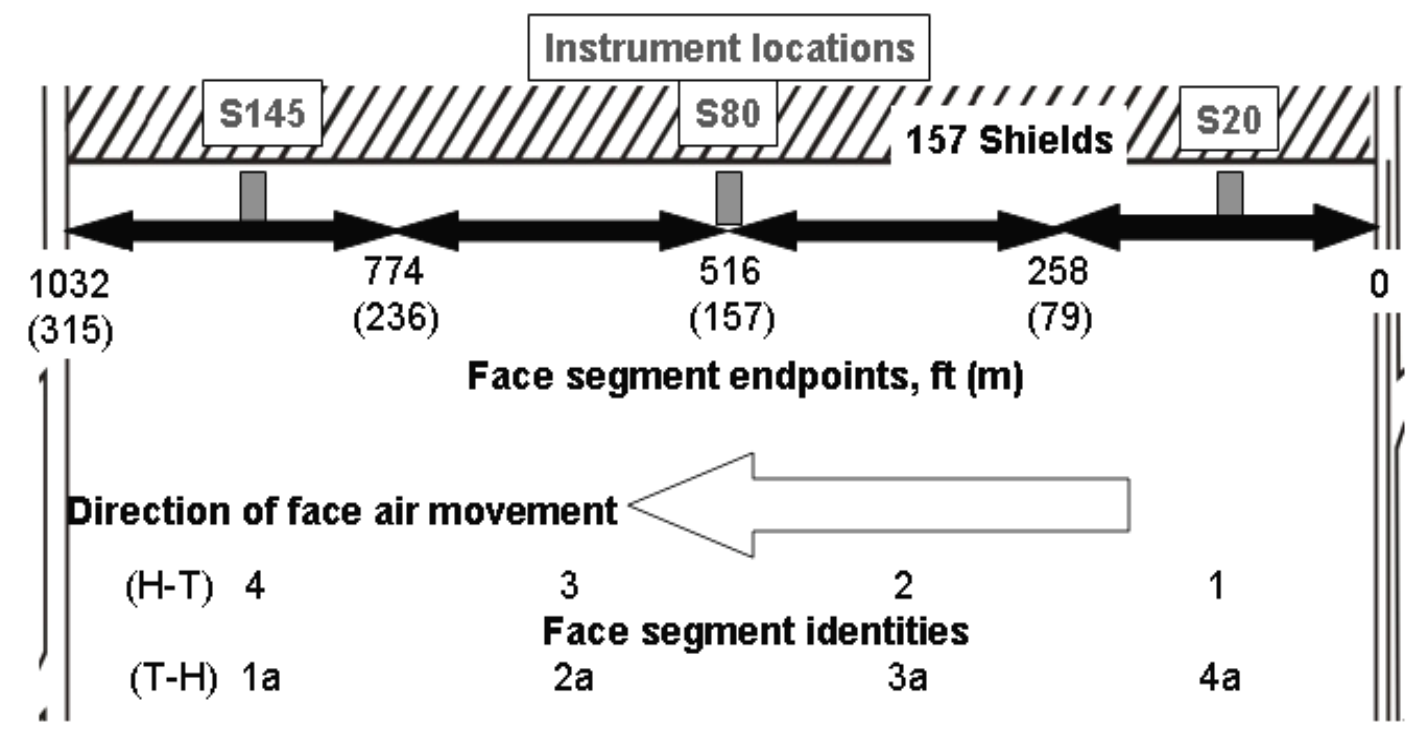

Figure 2-6: Instrument locations for methane emissions - recordings based on continuous data recorder place at 258 feet intervals across face ${ }^{19}$.

tailgate corners to avoid the inclusion of large amounts of ventilation air at the headgate and tailgate corners which did not traverse the face. Due to the

\footnotetext{
19 "Data Prediction of longwall methane emissions and the associated consequences of increasing longwall face lengths: a case study in the Pittsburgh Coalbed", S.J. Schatzel, R.B. Krog, F. Garcia, and J.K. Marshall, NIOSH, Pittsburgh Research Laboratory, Pittsburgh, PA, USA, J. Trackemas
} 
limitation of methane sensors, only three sensor were available for monitoring of the face methane emissions. The methane sensors were installed at distances from the headgate corner to each monitoring location at 113.9, 516.5, and 952.5 feet $(34.7,157.4$, and $290.3 \mathrm{~m})$ for the 1,032 feet $(315 \mathrm{~m})$ face as depict in Figure 2-6. The distance of 1,032 feet $(315 \mathrm{~m})$ is the rib to rib face width for the nominal face width is 1050 feet $(320 \mathrm{~m})$.

Average methane emission rates were computed for each of the face segments using simple algebraic formulas to determine the methane volume emitted, which was then divided by the time required to mine each face segment. A total of 4 methane emission rates were computed for each $\mathrm{H}$-T pass and 4 methane emission rates for each $\mathrm{T}-\mathrm{H}$ pass. Each algebraic formula used for computing face segment emissions consisted of determining the difference between the average methane emissions quantity when the shearer was at the end of a segment and usually the average methane emissions quantity when the shearer was located at the beginning of the segment. This quantity was then divided by the time elapsed in the mining of the segment. All three methane sensors were used in this exercise and the nearest downstream methane sensor was used to compute the methane emission quantities. The travel time of ventilation air along the longwall face was determined and the duration of air flow to the sensors ranged from 0 seconds to about 1 minute in computing methane emission quantities. The shearer cut speed averaged 46 feet per minute $(0.23$ $\mathrm{m} / \mathrm{s})$, face conveyor chain length was 1032 feet $(315 \mathrm{~m})$, face conveyor speed was $353 \mathrm{ft} / \mathrm{min}(1.78 \mathrm{~m} / \mathrm{s})$, and longwall face airflow velocity was approximately 500 $\mathrm{ft} / \min (2.54 \mathrm{~m} / \mathrm{s})$. During the study, the measured average daily methane emission rates varied from about $98 \mathrm{cfm}\left(0.05 \mathrm{~m}^{3} / \mathrm{s}\right)$ to about $187 \mathrm{cfm}\left(0.09 \mathrm{~m}^{3} / \mathrm{s}\right)$ on head-to-tail passes over the three days of the study. The results of the study are shown in Figure 2-7 relative to total emissions from the headgate corner. Figure 2.8 indicate the results for each interval.

To further enhance the study, an analysis of the methane sources and their individual contributions to the total longwall methane emissions were determined 
from methane concentration data collected at the beginning and end of the longwall face, along with the shearer location and other relevant ventilation and

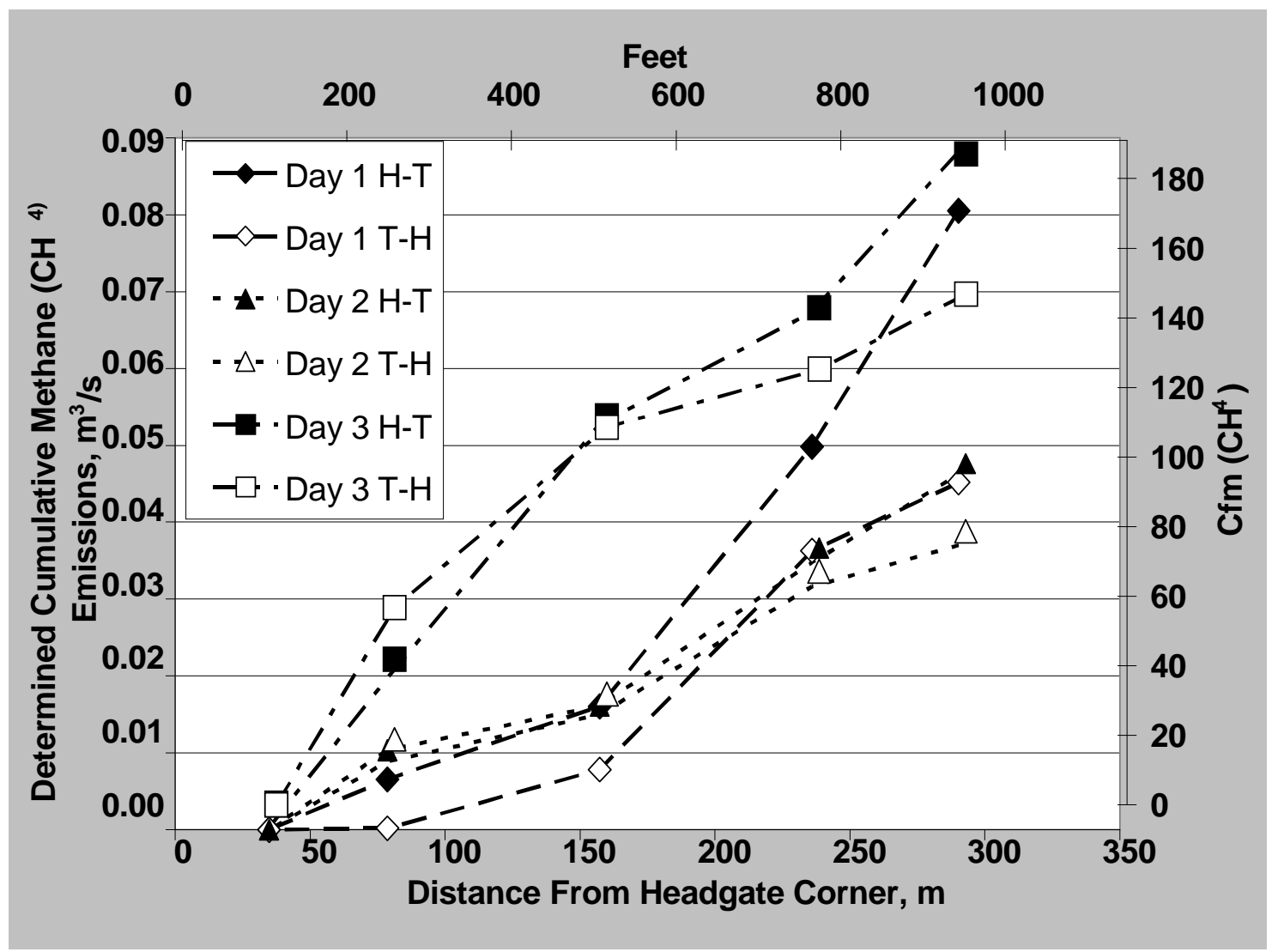

Figure 2-7: Methane emissions recordings - based on continuous data recorder place at across face relative to distance from headgate ${ }^{20}$.

mining data. The methane emission contributors from the mining of a longwall face that were evaluated were: 1) gas released from the coal broken by the shearer, 2) gas emitted from the broken coal on the face conveyor, 3) gas emitted from the coal transported on the belt, and 4) background gas emitted from the coal face and from the adjoining ribs in the intake gateroads. Once the methane contributions from the various sources were defined for an actual

\footnotetext{
20 "Data Prediction of longwall methane emissions and the associated consequences of increasing longwall face lengths: a case study in the Pittsburgh Coalbed", S.J. Schatzel, R.B. Krog, F. Garcia, and J.K. Marshall, NIOSH, Pittsburgh Research Laboratory, Pittsburgh, PA, USA, J. Trackemas
} 
longwall cutting sequence, a delay free (no downtime) cut sequence can be predicted. The calculated methane emission contributions was then extrapolated to longer longwall faces, taking into account the variations in coal production and transport factors, to accurately predict future methane emission rates from longer longwall faces.

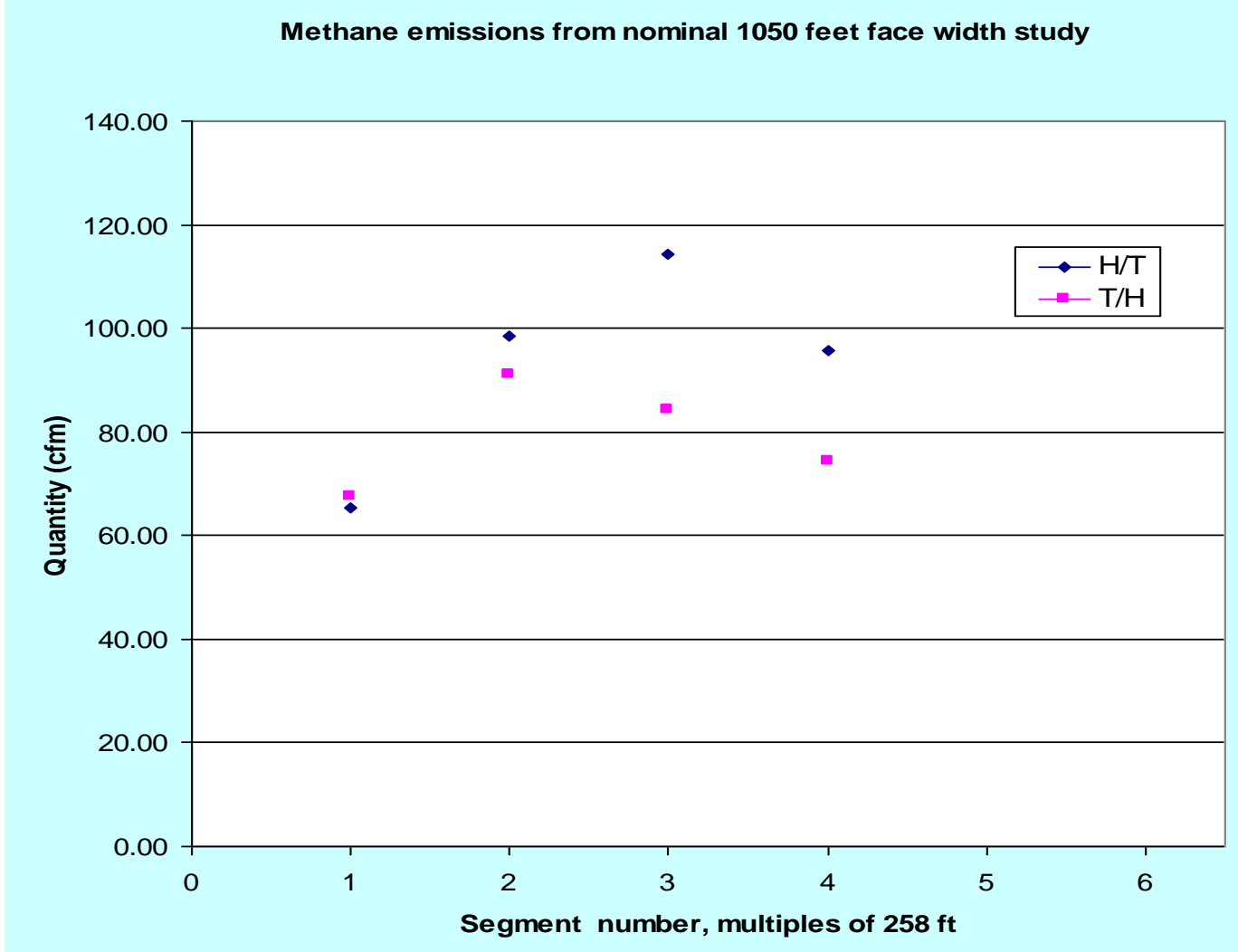

Figure 2-8: Methane emissions interval recordings - based on continuous data recorder based on each 258 feet intervals across face ${ }^{21}$.

Methane liberation was expected to increase by about $7 \%$ above its previous level for every 100 foot increase in face width, and the pressure drops about -0.04 inch for every 100 feet of panel width. This results in a requirement of

21 "Data Prediction of longwall methane emissions and the associated consequences of increasing longwall face lengths: a case study in the Pittsburgh Coalbed", S.J. Schatzel, R.B. Krog, F. Garcia, and J.K. Marshall, NIOSH, Pittsburgh Research Laboratory, Pittsburgh, PA, USA, J. Trackemas 
an additional 1,500 cubic feet of air per minute for each 100 feet of face width. The current 50,000 to 60,000 cubic feet per minute of airflow across the face was estimated to be adequate to handle the additional methane, and overcome the minimal pressure drop. Table 2-6 illustrates the required quantities and resistances for the extend face widths. The 1,050 feet face $(320 \mathrm{~m})$ resistance was established from previous ventilation surveys, and the projected face widths are calculated from two basic ventilation formulas using substitution of values to solve for the unknowns:

$$
H=R Q^{2} \text {, and } H_{f}=\left(K P L Q^{2}\right) / 5.2 A^{3} \text { (Atkinson Formula) }
$$

Where " $H$ " and " $H_{f}$ " is the head loss, "R" is the resistance, $Q$ is the quantity of the airway, "K" is the friction factor of the airway, "P" is the perimeter of the airway, "L" is the length of the airway, and "A" is the area of the airway.

Table 2-6: Face ventilation resistance and quantity requirements ${ }^{22}$.

\begin{tabular}{|c|c|c|c|}
\hline Face Length & Resistance & Pressure Loss & Quantity \\
\hline 1050 Feet $(320 \mathrm{~m})$ & 0.81 & 0.25 & 55,000 \\
\hline 1250 Feet $(381 \mathrm{~m})$ & 0.98 & 0.33 & 58,000 \\
\hline 1500 Feet $(488 \mathrm{~m})$ & 1.18 & 0.47 & 63,250 \\
\hline
\end{tabular}

The results of this study to predict longwall face methane emissions at increasing face widths is site specific and includes all delays which occurred during the monitoring period. The methodology of using a least-squares-regression, linear fit to the averaged data for all shearer passes and a projection to wider face lengths produced an $R^{2}$ value of 0.993 . Due to the higher rate of face methane emissions measured during $\mathrm{H}-\mathrm{T}$ passes, linear trend line for methane liberation was fit to only the averaged $\mathrm{H}-\mathrm{T}$ passes as this was considered a better predictor of hazardous methane emission conditions on longer faces for this study. Using trend line developed from the H-T pass data, longwall faces lengths of 1,250 feet

${ }^{22}$ Data in Table was obtained gathered by author through calculations. 
$(381 \mathrm{~m})$ and 1,600 ft (488 $\mathrm{m}$ ) yielded predicted methane emission rates of $199 \mathrm{cfm}$ $\left(0.09 \mathrm{~m}^{3} / \mathrm{s}\right)$ and $262 \mathrm{cfm}\left(0.12 \mathrm{~m}^{3} / \mathrm{s}\right)$, respectively, with an $R^{2}$ value of 0.983 . See Figure 2.9 for results. The maximum velocity of air required will not exceed 700 feet per minute $(3.5 \mathrm{~m} / \mathrm{s})$ at the anticipated maximum width of 1600 feet $(488 \mathrm{~m})$.

From the study, it was also determined that the expected peak methane emission increases for wider longwall panels are primarily from the coal transported on the face conveyor, the background emissions ( coal on section belt, rib liberation along belt, etc.), and from the exposed coal on the face. Using intake belt air to the longwall face carries all the methane liberation associated with rib liberation of the gateroad section belt entry and the recently mined coal on the belt, across the longwall face as intake air ventilation. The methane emission increases related to the transport of coal on the face conveyor is more significant for longer longwall faces because wider face having longer mining passes. The elimination of the use of section belt air to ventilate the face will be beneficial to reduce methane delays. Also, the use in-seam degasification methods to reduce methane content within the coal seam have been beneficial. In seam drilling of horizontal degas "shielding" holes have help reduce methane during development, as well as degas prior to longwall retreat. These horizontal holes can be drill from a drill rig positioned within the mined entry up to a distance of 4000 feet hole length (1219 $\mathrm{m}$ ), and maintain to within 50 to 75 feet (15 to $25 \mathrm{~m}$ ) of the projected outside entries of the CM section. The holes generally produce between 150,000 to 250,000 feet $^{3}$ per day of methane. The limitation on this process is the horizontal holes can not be drill until the mining is completed in the area where drilling is to start. Therefore the period of time available for the holes to produce and degas is limited. In recent years, vertical holes have been drilled with horizontal laterals to produce methane from the coal seam in advance of mining. The holes have been very successful in removing as much as one half of the in-situ gas prior to mining. The initial hole is drilled vertically with another hole drill vertical to intercept the first hole for dewatering purposes. As many as three lateral horizontal hole are then drilled from the vertical hole. The lateral horizontal holes are approximately 3000 
feet long. Each lateral horizontal hole produces about 250,000 to 350,000 feet $^{3}$ per day of methane, with the connected vertical hole producing about one million feet $^{3}$ per day for all the horizontal laterals. This process has been very successful and can be done in advance of mining to allow adequate drainage time for methane.

The mine also currently uses vertical gob ventilation boreholes to remove methane from the gob prior to the methane reaching the bleeder system. These boreholes are placed within 500 feet of the set-up entry, and then spaced every 2000 feet along the panel and within 350 feet of the tailgate entry into the gob area. To determine possible additional vertical degasification needs, a 3-D dynamic reservoir model was developed to simulate methane produced in the gob from the longwall operation. This model was developed through $\mathrm{NIOSH}$. Increasing the longwall panel width by 200 feet would result in an additional 477 cubic feet per minute of methane being produce in the gob. It was determine from current designs that system had adequate capacity to support panel width up to 1450 feet. It was determined that additional boreholes be placed on the headgate side of the panel for the 1600 feet panel width. The placement of these holes will be a mirror image of the tailgate side of the panel, the first hole will be placed within 500 feet of the set-up entry and every 2000 feet along the panel length and within 350 of the headgate belt entry into the gob area. The holes are predicted to remove approximately $75 \%$ of the additional methane liberated. 


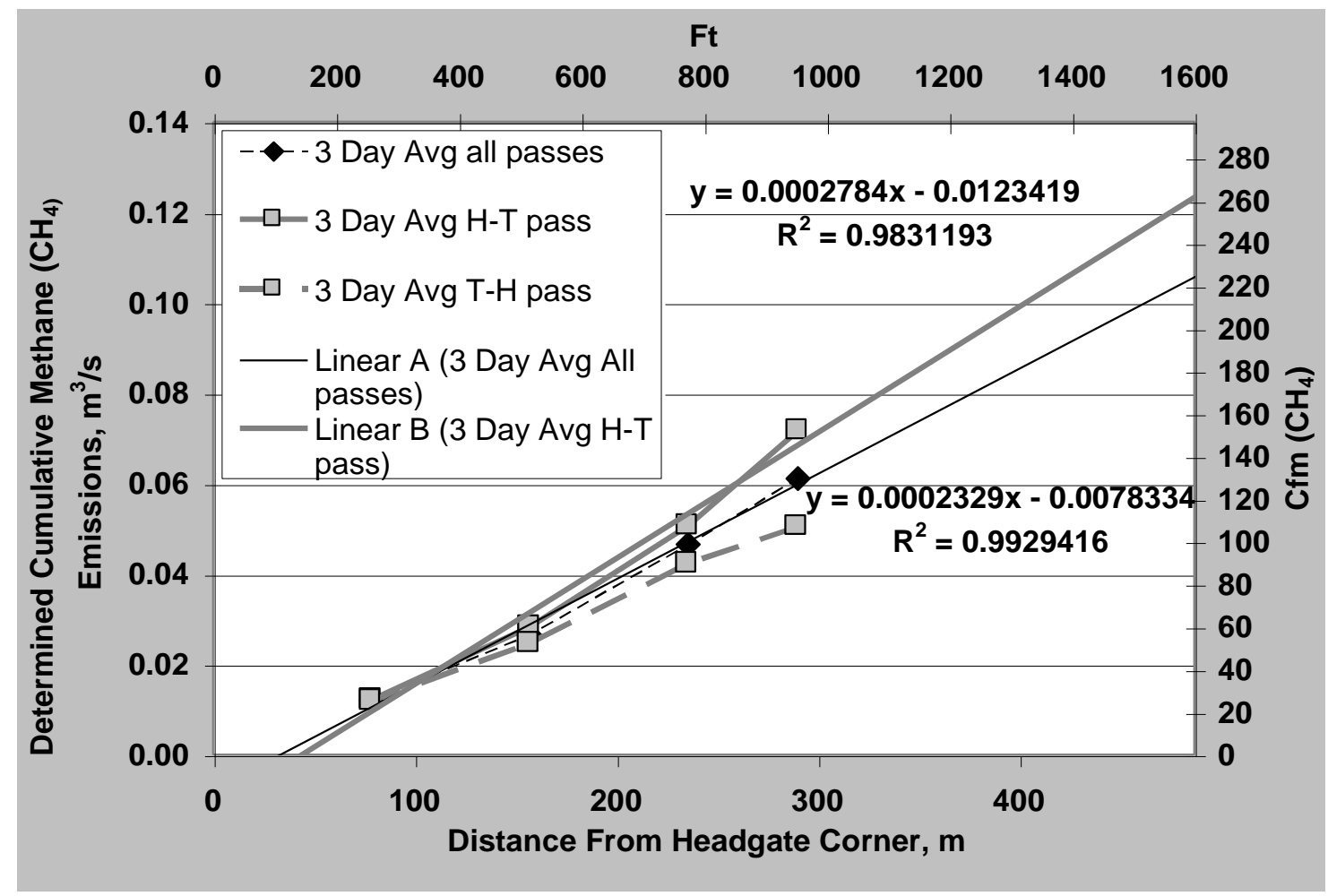

Figure 2-9: Regression Analysis Results ${ }^{23}$.

\subsection{Mine and System Infrastructure}

Changes created by widening the longwall face are likely to affect other factors related to the mine and system infrastructure that will need to be further reviewed. The handling of the larger and heavier AFC drives during installation and longwall moves were reviewed. An alternative that is commonly used at other mines was the use of a two piece base for the headgate drive. This two piece base design will eliminate handling of anything heavier or larger dimensions than is currently handled by the mine previously. Designing the headgate drive base in two pieces will add to the underground setup timing during a longwall move, but would reduce the weight and size requirements for hauling this equipment from place to place and eliminate the need for possible modifications to the mine hoist system and the

\footnotetext{
23 "Data Prediction of longwall methane emissions and the associated consequences of increasing longwall face lengths: a case study in the Pittsburgh Coalbed", S.J. Schatzel, R.B. Krog, F. Garcia, and J.K. Marshall, NIOSH, Pittsburgh Research Laboratory, Pittsburgh, PA, USA, J. Trackemas
} 
mobile equipment used to transport the drive underground. Making the headgate drive a two piece base eliminates concerns with entry dimensions of the mine slope, outby haulage entries dimensions, and track requirements to handle heavier loads.

The longwall tailgate rock dust system was modified to account for the wider face and subsequent longer transport distance of the dust through the system. This modification was a simple modification to the computer programming operating the duster.

The water system for dust suppression was reviewed for the increase distance. The current water pumps were adequate with the minor additional line losses calculated. The ability to increase the size of the face hosing in the accessory trays was also an option to overcome any line losses, if needed.

Longwall moves were also reviewed for possible changes or affects. Approximately, each additional 100 feet of face width requires the addition of 15 two meter shields. The normal move time for face width of 1050 feet with a complete extra face conveyor and electrical system takes approximately 12 days. The increase in face width from a 1050 feet face width to 1250 feet face width resulted in an additional 2 days of move time for additional equipment and hosing required resulting in a 14 day move time. The increase in face width to 1600 feet resulted in an anticipated longwall move time of 17 days and 2 shifts. This additional move time was a result of the extra equipment, larger drive motor cables, extra hydraulic hosing, and 2 shifts were added to account for the removal of larger drive power units and the two piece headgate drive base on recovery.

Power moves were also reviewed because of the larger power centers, additional hydraulic hose, and larger drive power cables. After review, no significant change in time or work resulted from the change.

Additional work was completed to review the effects on component life due to the extend panel life and additional tons, as shown is Table 2.7. Since there are considerably more tons in each panel, the equipment had to last longer between rebuilds, or in some cases mid-panel repair change outs had to be considered. 
The higher wear items, such as the face conveyor chain and sprockets, shearer components, stageloader chain and sprockets were review. The current wear on the components require no additional changes or maintenance time that was currently planned from the 1050 feet face when extended to 1250 feet width. When the face was widened to 1600 feet, additional maintenance would be required. The face conveyor chain would only be used for one panel instead of the reuse on the second panel as previously done. The headgate sprocket would be changed out during a mid-panel planned maintenance period. The tailgate sprocket would be strategically spotted in the tailgate entry or a box made up near the tailgate on the face to house a spare sprocket. The shearer would undergo a component change out including cutting drums during the mid-panel planned repair period. Currently, work is continuing with the equipment manufacturers to improve product/component life to reduce or eliminate the mid-panel change out of components.

Table 2-7: Increase in raw tons for extended panel widths - panel length is 10,000 feet $(3,048 \mathrm{~m})$, mining height is $7.5 \mathrm{feet}$; material in place $93.7 \mathrm{lbs} / \mathrm{ft}^{324}$.

\begin{tabular}{|l|c||c|c|}
\hline Face width in feet & 1,050 feet $(320 \mathrm{~m})$ & 1,250 feet $(381 \mathrm{~m})$ & 1,600 feet $(488 \mathrm{~m})$ \\
\hline Raw Tons per cut & $1,291(1,173 \mathrm{t})$ & $1,537(1,397 \mathrm{t})$ & $1,854(1,686 \mathrm{t})$ \\
\hline $\begin{array}{l}\text { Raw Tons in Panel in } \\
\text { millions }\end{array}$ & $3.69(3.35 \mathrm{t})$ & $4.39(3.99 \mathrm{t})$ & $5.30(4.82 \mathrm{t})$ \\
\hline $\begin{array}{l}\text { Additional Raw Tons per } \\
\text { panel in millions }\end{array}$ & $+0.7(+0.64 \mathrm{t})$ & $+1.61(+1.47 \mathrm{t})$ \\
\hline Percent increase in tons & +19.0 & +46.1 \\
\hline
\end{tabular}

\footnotetext{
${ }^{24}$ Data in Table was obtained gathered by author through calculations.
} 
CHAPTER 3: SUMMARY AND CONCLUSIONS

While in the 1970 s and 1980 s, up to $25 \%$ of the coal produced from a longwall mine would come from development, this has dropped considerably and now tends to be around $10 \%$ in a modern operation. However, gateroad development is becoming the major cost driver in longwall mines. Improved longwall technology and resulting retreat rates continue to make advance rates of continuous miners critical factors in the cost-effectiveness of longwall mines. The changes in longwall methods and mining operations are significant and are forcing a catch-up process for $\mathrm{CM}$ development. The aim of using a wider face is to reduce the longwall retreat rate without sacrificing productivity, and thereby reducing the pressure on increasing panel development rates. However, a systematic approach is being used to analyze potential increases in performance and production; as well as, assess the risk potential in the decision making process to move forward with extended longwall face widths. Each part of the overall longwall system contains its own inherent potential risk characteristics. Moving forward to field test each part is the next step in this evaluation. This process does not end with the analysis of one process, continued observations and data collection in variable conditions were required to evaluate the performance as a complete system. Also, the evaluation of the difference in required maintenance relative to the larger face conveyor equipment, multitude of mechanical and hydraulic component requirements, and manpower are required. The increase in face width inherently translates into increases in the level of, and an increase in the time required for tear-down and installation time during the moves between panels. These processes were also reviewed and evaluated through underground observations. Since technology is always advancing, projects need reviewed again and again to further reduce the risk.

Testing started with the initial base case of 1050 feet panel width and increasing to the panel width of 1250 feet. The hydraulic system was upgraded from the stageloader, through the monorail, to the pump station. Additional shields and panline sections were added to the face conveyor as required to complete a 
nominal width of 1250 feet. Additional ventilation quantity was available to the face and no electrical; roof control; or mine and system infrastructure changes were required. After having mined four panels, the 1,250 feet wide case can be described as very successful. In general the performance expectations were all fully accomplished. There were no armored face conveyor issues, hydraulic system issues, electrical issues, roof control issues, ventilation issues, nor mine and system infrastructure problems experienced. The equipment design proved to be correct with monitoring of the face conveyor loading of electrical current demand. The longwall float times improved dramatically, and longwall productivity improved. In the fourth 1,250 feet wide panel the larger conveyor gearboxes and 1,650 horsepower motors together with the $48 \mathrm{~mm}$ chain were tested for the next 1,600 feet wide panels. The results were encouraging as predicted. Due to geometry of the reserve, panel widths incrementally stepped up from 1250 feet width to nominal widths of 1370 feet, to 1405 feet, to 1424 feet, and then finally to 1580 feet width. Through the varying face widths changes were made to the armored face conveyor, hydraulic system, electrical, and ventilation. Changes were not observed, nor required to the roof control, or mine and system infrastructure. The current roof control system with respect to pillar design, bolting, and pumpable crib supports proved adequate. The current scoops with a 50 ton lifting capacity and sectionalizing the drive units required no changes to the mine and system infrastructure.

Now after the original longwall starting in January of 1981, the mine has completed mining the 60th longwall panel during August 2012. Starting in September 2012, currently the widest longwall face operating in the United States with the width of 1580 feet $(482 \mathrm{~m})$ is operating successfully, and will be moved in June of 2013. The potential gains from increasing face widths as technology allows, certainly has proven substantial benefits in mine timing logistics, production, and reserve recovery. 
CHAPTER 4: RECOMMENDATIONS

Through engineering design and field observations, extended longwall faces have proven to be successful with the current available technology. The limiting factor to current technology is the armored face conveyor. This limitation is to both the existing power units and face conveyor chain. Each mine has conditions specific to its own application. It is recommended that each mine should conduct an in depth review of the site specific conditions to identify differences and conduct a risk assessment to enable the advantages of wider longwall faces to become a successful part of their business model. 


\section{REFERENCES}

1) "History of Coal Mining", St. Vincent College, web page : http://facweb.stvincent.edu/eec/MRIP/history of coal mining.htm, 2002

2) "Longwall Mining", Energy Information Administration, Office of Coal, Nuclear, Electric and Alternate Fuels, U.S. Department of Energy, March 1995

3) "1960s: Coal Fuels America's Critical Electrical Background", Coal Age $100^{\text {th }}$ Anniversary Special Issue, August 2012

4) “Longwall Mining" second edition, Syd S. Peng, 2006

5) "Analysis and prediction of longwall methane emissions: a case study in the Pocahontas No. 3 Coalbed, VA." NIOSH Report of Investigations (RI 9649), Diamond, W.P., Garcia, F. 1999.

6) "Data Prediction of longwall methane emissions and the associated consequences of increasing longwall face lengths: a case study in the Pittsburgh Coalbed", S.J. Schatzel, R.B. Krog, F. Garcia, and J.K. Marshall, $\mathrm{NIOSH}$, Pittsburgh Research Laboratory, Pittsburgh, PA, USA, J. Trackemas, 2006 


\section{CURRICULUM VITAE}

\section{Jack Trackemas}

\section{PROFESSIONAL SUMMARY}

Over THIRTY years of mining experience in progressively responsible positions. Experience includes positions such as Mine Engineer, Foreman, Safety Manager, Technical Services Manager, Mine Manager, Director of technical Services, general manager.

Engineering experience includes all aspects of new and existing mine planning and design with respect to ventilation, roof control, and general operational and compliance layout requirements. Have authored and coauthoring papers dealing with mine subsidence effects, roof control, ventilation, and longwall design.

Safety experience includes implementing and maintaining safety compliance and programs for reducing accidents and citations at both union and union free environments.

Mine manager experience includes operation of a union free mine with over 300 employees operating three continuous miner units and one longwall on a seven day per week schedule.

General manager experience includes operation and budgeting of a union represented mine with over 700 employees operating four continuous miner units and one longwall on a seven day per week schedule. 


\section{EDUCATION}

Penn State University, State College, PA

Bachelor of Science in Mining Engineering, 1983

Graduated in the top five percent of the class

Penn State University, Uniontown, PA

Associate Degree in Mine Maintenance Technology, 1985

Graduated valedictorian of class

West Virginia University, Morgantown, WV

Master of Science in Mine Design

Current GPA is 4.0, all course work complete, currently completing thesis

\section{PROFESSIONAL CERTIFICATIONS}

Utah and Pennsylvania mine foreman certified

MSHA training instructor certified

Mine rescue trained

MSHA surface and underground methane detection certified

Pennsylvania miner and machine operation papers 


\title{
FACTORS CONSIDERED FOR INCREASING LONGWALL PANEL WIDTH
}

Jack D. Trackemas

Thesis submitted to the College of Engineering and Mineral Resources at West Virginia University in partial fulfillment of the requirements for degree of

\author{
Master of Science \\ in \\ Mining Engineering \\ Department of Mining Engineering
}

APPROVAL OF THE EXAMINING COMMITTEE

Syd S. Peng, Ph.D., Chair

Brijes Mishra, Ph.D.

Yi Luo, Ph.D.

Morgantown, West Virginia

May 2013 